\title{
Yeşil ve Düşük Karbonlu Ekonomiye Geçiş Sürecinde İşletmelerin Algı ve Tutumları: Bursa Örneği ${ }^{1}$
}

\author{
Yasemin Kaya ${ }^{\mathrm{a}}$
}

\author{
Sevda Gürsakal ${ }^{b}$
}

\begin{abstract}
Öz: Yeşil ekonomi, özellikle 2008 ekonomik krizinin ardından, hem krizi aşmak hem de ekonomileri yeniden canlandırmak konusunda yeşil yatırımlara öncelik verilmesi gerektiğine ilişkin söylemlerin güçlenmesiyle birlikte tüm ekonomilerin gündemine yerleşen bir kavram olmuştur. Mevcut sektörlerin karbondan arındırılması ve kaynak verimliliğinin artırılmasına ek olarak, yeşil sektörlere yatırım yoluyla büyümeyi canlandırma, daha kapsayıcı hale getirme ve sürdürülebilir kılma konusunda yeşil ekonomi önemli firsatlar sunan bir yaklaşım olarak değerlendirilmektedir. Bununla birikte yeşil ekonomi, uluslararası ilişkilerden, kamu ve özel sektör politiklarına, bireysel tutum ve davranışlara kadar pek çok alanda köklü bir değişim ve farklı bir algı gerektirmektir. Bu çalışmada yeşil ekonomiye geçiş süreci özel sektör açısından değerlendirilmektedir. Çünkü özel sektör kuruluşları bu süreçte en fazla rol üstlenmesi gereken örgütler olarak kabul edilmektedir. Çalışma özel sektör kuruluşlarının kendilerinden bekelenen dönüşümü gerçekleştirme konususunda istekli ya da gönüllü bir tutum içerisinde olup olmadıklarını araştırmayı amaçlamaktadır. Bu amaç doğrultusunda bir anket formu hazırlanmış ve Bursa ili bünyesindeki 8 organize sanayi bölgesinde faaliyet gösteren, farklı sektör ve farklı ölçeklerde 134 firmaya uygulanmıştır. Çalışmada öncelikle yeşil ekonomiye ilişkin kavramsal çerçeve ortaya konmakta daha sonra anket çalışmasından elde edilen sonuçlar analiz edilmektedir.
\end{abstract}

Anahtar Sözcükler: Yeşil Ekonomi, Düşük Karbonlu Ekonomi, Sürdürülebilir Kalkınma, Bursa, Yeşil İşletmecilik

JEL Sınıflandırması: 013, 040

\section{Business' Perceptions and Attitudes in Transition Process to Green and Low- Carbon Economy: Bursa Case Study}

\begin{abstract}
Green economy has become a central concept with the advent of the arguments contending green investments should take precedence in order to both prevent crisis and revitalize economies especially after the 2008 economic crisis. Green economy is regarded as an approach that presents significant opportunities in rendering the growth more inclusive and sustainable as well as invigorating the economy via investment in new green sectors, increasing productivity of resources and enabling the decarbonation of existing sectors. However green economy requires fundemental changes and a different perception in various venues such as international relations, private and public sector policies, personal behaviors and attitudes. In this study, transition to the green economy has been evaluated from the perspective of private sector since private organisations are viewed as the ones that should play a role. The study intends to inquire whether the private sector institutions are willing to carry out the expected transition or posses a voluntary attitude towards it. A survey form has been prepared to measure it and implemented to 134 firms of various scales and sectors in 8 orginized industrial zones in Bursa. First a coneceptual framework has been laid out for the green economy and then survey results has been analyzed.
\end{abstract}

Keywords: Green Economy, Low-Carbon Economy, Sustainable Development, Bursa, Green Business

JEL Classification: 013,040

\footnotetext{
aAsst. Prof., PhD., Uludag University, Faculty of Economics and Administrative Sciences, Department of Public Administration, Bursa, Turkiye, yaseminkahveci@uludag.edu.tr

${ }^{b}$ Assoc. Prof., PhD., Uludag University, Faculty of Economics and Administrative Sciences, Department of Econometrics, Bursa, Turkiye,sdalgic@uludag.edu.tr
} 


\section{Giriş}

Çevre ve ekonomi ikilemi uzun yıllardır hem akademik hem de politik tartışmaların odağında olan bir sorundur. Geçen yarım yüzyıllık süreçte sağlanan ekonomik büyümenin büyük ölçüde çevresel değerlerin kaybı pahasına gerçekleştiği ve bu büyüme sürecinin ne sürdürülebilir ne de kapsayıcı olduğu yönündeki eleştiriler giderek artmaktadır. Refah göstergeleri, büyüme rakamlarındaki artışa rağmen, hâlâ 1.3 milyar insanın elektriğe erişiminin olmadığını, 2.6 milyar insanın gerekli hıfıısıhha şartlarına sahip olmadığını ve yaklaşık 1 milyar insanın temiz ve güvenli içme suyuna erişimin bulunmadığını ortaya koymaktadır (WB, 2012: $x i, 6)$. Çevresel göstergeler ise ekosistem hizmetlerinde hayati nitelikte aksamalara neden olabilecek önemli sorunlara işaret etmektedir. Ekolojik ayak izi ${ }^{2}$ hesaplamalarına göre doğanın sunduğu ekolojik hizmetlerden bugünkü düzeyde yararlanabilmemiz için, dünyanın kendini yenileme kapasitesinin 1,5 katına ihtiyaç duymaktayız (WWF, 2014: 9-10). Yani yıllık tüketim, gezegenin yıllık biyolojik üretken kapasitesini \%50 aşmaktadır. Bunun anlamı yenilenebilir kaynakların, kendilerini yenileyebilme hızlarının çok daha ötesinde bir hızla tüketildiğidir. Bu durum ancak kaynak stoklarının tükenmesiyle mümkün olabilir ki, bu da gelecek nesiler açısından önemli bir kaynak kıtlığına işaret etmektedir.

İnsanoğlunun gezegen üzerinde yarattğı etkiyi gözler önüne seren ve karşı karşıya kalınan riskin boyutlarını aydınlatan dikkat çekici bir çalışma da 'gezegen eşikleri çerçevesi' dir. Gezegen eşikleri çerçevesine göre, Dünya sistemindeki biyolojik ve fiziksel süreçlerin devamı için aşılmaması gereken dokuz eşik belirlenmiştir. ${ }^{3}$ Eşikler hep birlikte, insanlığın güvenli bir faaliyet alanı için gereksinim duyduğu ortamı oluşturmaktadır. Güvenli faaliyet ve yaşam alanını tanımlayan eşikler, ani ve büyük boyutlu değişikliklerin ortaya çıkabileceği belirsizlik bölgelerinin en alt sınırını belirlemektedir. Yapılan analizler, bu eşiklerinden üçünün -atmosferdeki karbon yoğunluğu, biyolojik çeşitlilik kaybı, azot ve fosfor döngösü- aşıldığını göstermektedir (Folke, 2013: 31-36).

Bu veriler mevcut büyüme, üretim ve tüketim kalıplarının açık şekilde sürdürülemez bir geleceğe işaret ettiğini göstermektedir. Bu durum aynı zamanda ekonomik yapıda köklü bir dönüşüme gidilmesi gerektiğini de ortaya koymaktadır. Bu dönüşümü kaçınılmaz hale getiren önemli bir sorun da kuşkusuz iklim değişikliğidir. İklim sisteminde ortaya çıkabilecek ani, geri döndürülemez ve felakete varacak değişimlerin önlenmesi için ıSı artş̧ının endüstri öncesi döneme göre (1850-1900) $2^{\circ} \mathrm{C}$ ile sınırlandırılması gerektiği kabul edilmektedir. Hükümetlerarası İklim Değişikliği Paneli (Intergovernmental Panel on Climate Change IPCC)'nin Beşinci Değerlendirme Raporu, ISı artışını $2^{\circ} \mathrm{C}$ ile sınırlamak için karbon emisyonlarında 2010 yılı değeri temel alınmak üzere 2050 yılı itibarıyla \% 41-78 ve 2100 yılı itibarıyla \%78 - \%118 oranında bir azaltım gerektiğini ortaya koymaktadır (IPCC, 2015: 22). Bu tespit fosil yakıtların kullanımına son verilmesi ve ekonomilerin karbondan arındırılması gerektiği anlamına gelmektedir. Bu gereklilik, iklim Değişikliği Çerçeve Sözleşmesi'nin Paris'te düzenlenen 21. Taraflar Konferansında kabul edilen Paris Anlaşması'na da yansımış ve Anlaşma'da ortalama ısı artş̧ııın endüstri öncesi döneme göre $2^{\circ} \mathrm{C}$ daha altında ve mümkün olduğunca $1.5^{\circ} \mathrm{C}$ seviyesinde tutulması amacı kabul edilmiştir. Ayrıca iklime dirençli ve düşük karbonlu kalkınma modellerinin benimsenmesi gerektiğine dikkat çekilmiştir. ${ }^{4}$ Paris Anlaşması'nda ortaya konan hedefin tüm dünya ekonomileri üzerinde köklü bir dönüşüm gerektirdiği açıktır. 4 Kasım 2016'da yürürlüğe giren Anlaşma, tüm taraf devletlerden belirlenen hedefe ulaşmayı sağlayacak şekilde sera gazı salınımlarını azaltmalarını ve ekonomilerini bu yönde dönüştürmelerini beklemektedir.

Ekonomik yapıdaki dönüşüm için tayin edilen yeni rota ise son yıllarda giderek daha popüler hale gelen 'yeşil ekonomi' dir. Yeşil ekonomi, hem ekonomik faaliyetlerin çevre üzerinde yarattı̆ı baskıyı azaltmayı, hem yeşil sektörlere yatıım yoluyla yeni iş alanları yaratarak ekonomik canlanmayı sağlamayı hem de kalkınmanın etkisini genele yayarak sosyal dışlanmayı azaltmayı amaçlayan bir politika olarak kabul edilmektedir. Başka bir ifadeyle yeşil ekonomi, çağımızın karşı karşıya kaldığı ekolojik, ekonomik ve toplumsal krizlere çözüm üretmesi beklenilen bir politika yaklaşımını ve yeniden yapılanma sürecini ifade etmektedir.

Yeşil ekonomiye geçiş sürecinin gerektirdiği yapısal dönüşüm uluslararası ilişkilerden, kamu ve özel sektör politikalarına, bireysel tutum ve davranışlara kadar pek çok alanda önemli değişiklikler gerektirmektedir. Ancak bilindiği üzere çevre üzerinde yaratılan küresel baskıda özel sektör kuruluşları hem emisyon ve atık üretimi hem de kaynak tüketimi açısından büyük bir paya sahiptir (Ford, 2011:35). Bu nedenle 
ekonomin başat aktörleri olarak özel sektör kuruluşlarının sürdürülebilir kalkınmanın başarılmasında ve yeşil ekonomiye geçişte önemli roller üstlenmesi gerekmektedir. Özel sektör kuruluşlarının çevresel ve sosyal sorumluluklarını dikkate alan bir perspektif ve yeni davranış modelleri ile bu süreci desteklemeleri, yeşil ekonomi politikalarının hayata geçirilmesinde büyük önem arz etmektedir (Karbassi vd., 2011: 4). Ayıca yeşil ekonomiye geçiş için gerekli olan yatırımların önemli bir bölümünün de (yaklaşık \%85) özel sektör tarafindan üstlenilmesi beklenmektedir (G20-GFSG, 2016: 6; iklim Platformu, 2010: 13).

Yeşil ekonomi, Birleşmiş Milletler, Avrupa Birliği, OECD gibi uluslararası örgütlerin söylem ve politikalarında giderek daha hâkim hale gelmektedir (EFFECT, 2013: 3). Bu doğrultuda devletler, kendi kalkınma politikaları ve stratejilerini yeşil ekonominin gerekleriyle uyumlu şekilde yeniden formüle etmekte; yatııı, vergi ve teşvik politikalarını bu eksende şekillendirmektedir. ${ }^{5}$ Sera gazı emisyonlarının azaltımasına yönelik olarak uluslararası anlaşmalar bağlamında taahhüt ettikleri azaltım yükümlülükleri de devletlerin ekonomilerini karbondan arındıracak strateji ve politikalar geliştirmeleri ile sonuçlanmaktadır. Bu gelişmeler tüm ülkelerde özel sektör kuruluşlarının er ya da geç bu değişim ve geçiş süreci ile yüzleşmeleri gerektiğini ortaya koymaktadır. Bu alanda yapılan çalışmalar, süreci takip eden, gerekliliklerini öngören, farkındalığı yüksek ve bu alanda öncü olan şirketlerin önemli firsatlar yakalayabileceğini ortaya koymaktadır (Huberman, 2010: 33-37). Ancak çevresel maliyetlere ilişkin geleneksel algılar, özel sektör kuruluşlarının bu sürece gönüllü ve aktif bir biçimde katılımını engelleyebilmektedir. Özel sektör kuruluşlarının meseleye bu geleneksel algıyı aşan farklı bir perspektiften bakabilmesi, sürece etkin şekilde dâhil olmalarındaki en önemli faktörlerden biridir.

Bu açıdan özel sektör kuruluşlarının yeşil ekonomiye ilişkin algı ve tutumları yani dönüşüm sürecinde kendilerinden beklenen rolleri yerine getirme konusunda istekli ya da gönüllü olup olmadıkları sorusu önem kazanmaktadır. Bu alandaki yazın değerlendirildiğinde, yeşil ekonomiye ilişkin yayınların hızla artığı görülmektedir. Ancak bu yayınların ağırlıklı olarak yeşil ekonomiye ilişkin kavramsal bir çerçeve oluşturmaya odaklandığı söylenebilir. ${ }^{6}$ Son yıllarda yeşil ekonomi uygulamları, yeşil ekonomiye ilişkin performans göstergeleri ve ülkelerin yeşil ekonomi performansları dikkat çeken konular haline gelmektedir. Bununla birlikte yabancı yazında özel sektörün yeşil ekonomiye ilişkin tutumunun belirlenmesine yönelik çalışmalara da rastlanmaktadır (Bkz. Karbassi vd., 2011; AIG, 2007; EC, 2013; State of California, 2010; Kuszewski ve Crowther, 2012; Constantinos vd., 2010; Gregori vd., 2014). Yeşil ekonomi, Türkçe yazın için ise nispeten yeni bir konudur ve bu alandaki çalışmaların sayısı artmakla birlikte hala sınırlıdır. Bu alanda kavramsal çerçeveye odaklanan yayınların (Bkz. Aşıcı ve Şahin, 2012; Özçağ ve Hotunoğlu, 2015; Yalçın, 2016; Özsoy, 2015; Özsoy, 2011; Kuşat, 2013) yanı sıra düşük karbonlu ekonomiye geçiş için izlenebilcek politikaların, Türkiye ekonomisi üzerinde yaratacağı etkileri değerlendiren önmeli çalışmaların varlığına da dikkat çekmek gerekir (Bkz. Yeldan vd. 2015; TÜSIAD, 2016; Bouzaher, 2015). Özel sektörün konuya ilişkin algısının belirlenmesine yönelik olarak Türkçe yazında ulaşılan tek çalışma ise 2014 yılında Bölgesel Çevre Merkezi Türkiye Ofisi (REC Türkiye) ve TÜSiAD'ın işbirliği ile kurulan İklim Platformu'nca hazırlanan, 25 şirketin katkıda bulunduğu 'iklim Değişikliği CEO Algı Araştırması: Türk İş Dünyası Liderlerinin İklim Değişikliğine Yanıt" başlıklı rapordur. ${ }^{7}$ Bu yayın da iklim değişikliğine odaklanması anlamında yeşil ekonomi açısından sınırlı kalmaktır. Bu bağlamda araştırmanın özgün bir nitelik taşıdığı ve bu alandaki yazına katkı sağlayacağı düşünülmektedir.

Çalışmanın amacı, özel sektör kuruluşlarının yeşil ekonomiye ilişkin algı ve tutumlarını belirleyerek, dönüşüm sürecinde kendilerinden beklenen rolleri yerine getirme konusunda istekli ya da gönüllü olup olmadıklarını sorgulamaktır. İşletmelerin yeşil ekonomiye ilişkin algı ve tutumlarının belirlenmesinde saha çalışması için Bursa ili, önemli bir sanayi kenti olması sebebiyle tercih edilmiştir. Çalışma kapsamında bir anket formu hazırlanmış ve söz konusu anket seçilen 8 Organize Sanayi Bölgesinde (OSB) faaliyet gösteren firmalar arasından firma sayısına, sektör yoğunluğuna ve ölçeğe göre tabakalı örnekleme yoluyla belirlenen 134 firmaya uygulanmıştır. Anket verileri SPSS 18.0 paket programında analiz edilmiştir. Çalışmada öncellikle yeşil ve düşük karbonlu ekonomiye ilişkin kavramsal çerçeve belirlenecek ardından Dünya ve Türkiye'de kalkınma politiklarının yeşil ekonomi yönünde dönüşümünü gerekli kılan gelişmeler değerdirilecektir. Son olarak alan çalışmasından elde edilen veriler analiz edilecektir. 


\section{Yeşil ve Düşük Karbonlu Ekonomi}

Yeşil Ekonomi kavramı ilk defa 1989 yılında İngiliz Hükümetinin talebi doğrultusunda hazırlanan "Blueprint for a Green Economy" başlıklı raporda kullanılmıştır. 1991 yılında ise İngiliz Ekolojik iktisatçı Michael Jacobs yeşil ekonomi kavramına "The Green Economy: Environment, Sustainable Development and the Politics of the Future" başlıklı kitabında yer vermiştir. Ancak yeşil ekonomi kavramının temelleri, ileri endüstriyel toplumlarda çevresel kaygı ve endişenin artı̆ı 1960-1970'lerde atılmıştı (Ehresman ve Okereke, 2015: 15). Bu tarihlerde yayınlanan, çevreci hareketin ve ekolojik görüşün güçlenmesini sağlayan pek çok yayın, ekosistemin sınırlılıklarına uygun yeni bir ekonomik yapılanmaya ihtiyaç olduğuna dikkat çekmiş, bu yapının temel dinamiklerini tanımlamıştır. ${ }^{8}$ Çevre sorunlarındaki artışa paralel olarak güçlenen ekolojik düşünce, evrenin mekanik tarzda kavranışını, aydınlanmanın ideallerini ve maddi ilerlemenin sınırsızlığına olan inancı temelden sarsan görüşlerin güçlenmesi ve yayılmasını sağlayarak, insan-doğa ve ekonomi-ekoloji ilişkilerinin şimdikinden oldukça farklı bir temel üzerine inşa edilmesi gereğini ortaya koymuştur. Süreç içerisinde klasik iktisadın çevresel meselelere yaklaşımını eleştiren ve hâkim ekonomik paradigmayı sorgulayan yeni perspektiflerin gelişmesi de yeşil ekonomiye temel oluşturan fikir ve düşüncelerin olgunlaşmasına önemli bir katkı sağlamıştır (Hahnel, 2014).

Kavramın yaygın şekilde kullanımı ise 2008 yılı sonrasındadır. 2008 yılında finansal piyasalar başta olmak üzere yaşanan çok boyutlu küresel ekonomik krize yanıt olabilecek politikalar bağlamında, yeşil ekonomi önemli bir seçenek olarak yeniden gündeme gelmiştir. 2008 yılında Birleşmiş Milletler Çevre Programı (UNEP) temiz teknoloji, atık yönetimi, yenilenebilir enerji gibi yeşil sektörlere yatırımı teşvik etmek ve kirlilik/kaynak yoğun sektörleri ise daha yeşil hale getirmek konusunda hükümetlere politik destek sağlamak üzere Yeşil Ekonomi İnisiyatifi'ni oluşturmuştur. 2009 yılında İnisiyatifin katkısıyla, yeşil sektörlere yatırımı krize çözüm önerisi olarak sunan Küresel Yeşil Yeni Düzen (Global Green New Deal) raporu yayınlanmıştır (UNEP, 2009a). 2012 yılında gerçekleştirilen BM Sürdürülebilir Kalkınma Konferansı Rio +20'de ise yeşil ekonomi, sürdürülebilir kalkınma ve yoksulluğun azaltılması konularında temel bir strateji olarak kabul edilmiştir. Kavramı çok daha popüler hale getiren bu gelişmeyle birlikte yeşil ekonomi, sadece ekolojik değil aynı zamanda çok boyutlu küresel ekonomik krizinin (finansal kriz, petrol ve gıda krizi) aşılmasında temel bir politik reçete olarak kabul edilmiştir.

UNEP, yeşil ekonomiyi "refahı ve sosyal eşitliği arttırıen çevresel riskleri ve ekolojik kıtlıkları azaltan bir ekonomi" olarak tanımlamaktadır (UNEP, 2011:16). Bu yapı, karbon emisyonlarında azalma, kaynak kullanımında verimlilik ve sosyal dışlanmanın önlenmesi üzerine temellenmektedir. Bu politika, çevre üzerinde baskı yaratan ekonomilerin çevre performansını arttırmayı amaçlarken, yeşil sektör yatırımları ile yeni iş alanları ve mesleklerin yaratılmasına katkı sağlamayı hedeflemektedir. Bu açıdan yeşil ekonomi, hem ekonominin çevresel performansını artıran hem de yeni nesil kamu ve özel sektör yatırımları sayesinde gelir ve istihdam olanaklarında artş̧ sağlayan bir politika olarak tanımlanmaktır (UNEP, 2011:16). Bunun yanı sıra yeşil ekonomi gelir dağılımı ve firsat eşitliği gibi sorunlara karşıık, sosyal adalet ve sosyal içermeye ilişkin politika programlarını da kapsamaktadır. Kısacası, yeşil ekonomi, ekonomik kalkınmanın sadece ekolojik değil, sosyal boyutlarını da dikkate alan bir yaklaşımdır.

Yeşil ekonomiyle ilgili olarak UNEP'in yukarıdaki tanımı genel kabul görmekle birlikte, yeni bir kavram olması sebebiyle, yeşil ekonominin tam olarak ne anlama geldiği konusunda tartışmalar devam etmektedir. BM tarafindan yayınlanan Yeşil Ekonomi Rehberleri'nin kavramın tanımlanmasına odaklanan ilk serisinde, yeşil ekonomiye ilişkin olarak son yıllarda yayınlanan rapor, rehber, strateji belgesi gibi bir dizi doküman incelenmiş ve bu yayınlar bağlamında yeşil ekonomin en az 8 farklı tanımının olduğu ve yine benzer bir kavram olan yeşil büyümenin ise 13 farklı şekilde tanımlandığı belirtilmiştir (Allen ve Clouth, 2012: 63-63). Söz konusu tanımlar arasında bazı farklar olsa da genel itibariyle yeşil ekonomi, doğal varlıklar üzerindeki baskıyı azaltacak ve ekonomik büyüme için yeni firsatlar yaratacak şekilde ekonomi ve çevre politikalarının bütünleştirilmesini ifade eden bir politika olarak açıklanmıştır. Tanımların genel olarak üzerinde uzlaştı̆ı bir diğer konu da büyümenin sosyal boyutu, yani yeşil ekonomi politikalarının toplumsal kapsayıcılı̆ııdır. 
Yeşil ekonomiye dair ilkelerin belirlenmesine odaklanan ikinci rehberde ise yine bu alandaki yayınların değerlendirilmesinden yola çıkılarak üzerinde uzlaşılan ortak ilkeler belirlenmiştir (Allen, 2012a: 12). Bu ilkeler kavramın içeriğinin anlaşıması açısından önem taşımaktadır. Söz konusu ilkeler şunlardır;

- Yeşil ekonomi sürdürülebilir kalkınmanın başarılması için bir araçtır.

- Yeşil ekonomi insana yaraşır iş ve yeşil meslekler yaratmalıdır.

- Yeşil ekonomi enerji ve kaynak etkindir.

- Yeşil ekonomi gezegenin sınırlarına/ekolojik limit ve kıtıklara saygılıdır.

- Yeşil ekonomi bütünleşik karar almayı benimser.

- Yeşil ekonomi ilerlemeyi GSMH'nin ötesinde daha uygun gösterge ve ölçütler kullanarak ölçer.

- Yeşil ekonomi, ülke içi ve ülkelerarası ve nesiller arası eşitlik, adalet ve hakkaniyeti esas alır.

- Yeşil ekonomi biyolojik çeşitliliği ve ekosistemleri korur.

- Yeşil ekonomi, yoksulluğun azaltılmasını, refahı, sosyal korumayı ve temel hizmetlere erişimi sağlar.

- Yeşil ekonomi yönetişimi ve hukukun üstünlügünü destekler. İçerimci, demokratik, katılımcı, hesap verebilir, şeffaf ve istikrarlıdır.

- Yeşil ekonomi dışsallıkları içselleştirir.

Yeşil ekonomi politikalarının hayata geçirilmesinde kamu sektörünün öncü rolü oldukça önemlidir. Kamu yatırımları geçiş sürecinde gerekli alt yapının oluşturulmasını sağlayarak özel sektörün sürece katılımını kolaylaştıracak ve hızlandıracaktır. Ayrıca gerekli yasal çerçevenin oluşturulması, teşvik ve yatırım politikalarının revize edilmesi yoluyla kamu sektöründen yönlendirici bir rol üstlenmesi de beklenmektedir. Yeşil ekonomi kapsamında yatırımların yönlendirilmesi gereken temel yeşil sektörler, yenilenebilir enerji, düşük emisyonlu ulaşım ve toplu taşıma, enerji verimli binalar, çevreyle uyumlu kentsel alt yapı, sürdürülebilir tarım, ormancılık ve balıkçılık uygulamaları, atık ve su yönetimidir. Bu yatırımlardan ekolojik yararlarının (doğal sermaye stoğunu koruma ve çevresel bozulmayı önleme gibi) yanınında ekonomiyi canlandıracak bir çoğaltan etkisi yaratması beklenmektedir. Ayrıca yeni istihdam alanları ve mesleklerin gelişimi yoluyla, gelirin yeniden bölüşümüne katkı sağlama hedeflenmektedir (UNEP, 2011: 22,24; UNEP, 2009a: 6-12). Özel sektör kuruluşlarından ise yeşil ekonomiye ilişkin sinyalleri doğru algılamaları beklenmektedir. Çevre üzerinde yaratılan baskıyı hafifletecek, kaynakların etkin kullanımını sağlayacak yeni teknolojilerin geliştirilmesi ve uygulanması; üretim sürecini ve ürünü daha yeşil hale getirecek ar-ge çalışmalarının yürütülmesi ve yeşil sektörlere yatırımın hızlanması konularında özel sektörün girişimci vizyonu son derece önemlidir.

\section{Dünyada ve Türkiye'de Yeşil Ekonomi}

4-5 Eylül 2016 tarihinde Çin'in Hangzhou kentinde düzenlenen G20 zirvesinde yeşil ekonomiyle ilgili konulara yapılan güçlü vurgu, yeşil ekonomin küresel ekonomiye yön veren ülkelerin odağında olduğunu açıkça ortaya koymuştur. Zirve sonunda kabul edilen Liderler Bildirgesi'nde Sürdürürülebilir Kalkınma İçin 2030 Gündemi'ni ve Paris Anlaşması'nı dikkate alan güçlü, sürdürülebilir, dengeli ve kapsayıcı bir büyümenin temel bir amaç olarak benimsendiği görülmektedir (G20 Leaders' Communique, 2016).

Zirvede üzerinde durulan önemli bir konu da sürüdürülebilir büyüme için yeşil finansmanın önemidir. Yeşil Finasman Çalışma Grubu tarafindan hazırlanan raporda yenilenebilir enerji, enerji verimliliği, su ve atık yönetimi, yeşil bina ve temiz ulaşım gibi alanlarda hayata geçirilecek projelerin finansmanında kullanılacak bir araç olarak yeşil tahvillere dikkat çekilmekte; finans ve bankacılık sektörünün bu alandaki rolüne vurgu yapılmaktadır. Özel sermayenin sürüdürülebilir büyümeyi gerçekleştirecek yeşil yatırımlara yönelmesinde finasman sorunu önemli bir güçlük yaratmaktır. Bu nedenle söz konusu güçlüğü aşacak şekilde özel sektör 
yatırımlarını harekete geçirecek finansal desteğin sağlanması amacıyla yeşil finansman konusuna zirvede vurgu yapılmış olması kayda değer bir gelişme olarak yorumlanmalıdır.

Ayrıca zirvede enerji konusunda ekonomik, güvenli, sürdürülebilir ve düşük emisyonlu bir enerji geleceği hedeflendiği ortaya konmuştur. Bu çerçevede yenilenebilir enerji projelerine yatırımın önemine ve fosil yakıtlara verilen teşviklerin kaldırımasına dikkat çekilmiştir. Ülkelerin sera gazı azaltımıyla ilgili taahhütlerini yerine getirmeleri konusunda kararlı şekilde çaba göstermeleri, Paris Anlaşması şartlarına en kısa zamanda uygunluk sağlayarak Anlaşmayı onaylamaları ve Anlaşma'nın 2016 yılı sonuna kadar yürürlüğe girmesini sağlamaları liderlerin üzerinde uzlaşıya vardıkları konular olarak sonuç bildirisine yer almıştır (G20 Leaders' Communique, 2016).

Aslında yeşil büyüme ve düşük karbonlu ekonomi, 2009 Pitsburg ve 2010 Seul zirvelerinden bu yana G20 zirvelerinin ana gündemini oluşturmaktadır. 2008-2009 yıllarında yaşanan finansal krizden çıkış için yeşil yatırımları ekonomiyi canlandıracak bir çare olarak öneren 2009 zirvesini takiben pek çok ülkenin özellikle yenilenebilir enerji ve enerji verimliliği alanlarında yatırımlarını artırarak ekonomilerini karbondan arındırma ve düşük emisyonlu ekonomiye geçiş konusunda hızlı bir ilerleme gösterdeği söylenebilir. Güney Kore, Çin, Fransa, Almanya, ABD, Güney Afrika ve Meksika 2009 yılı verilerine göre ekonomiyi canlandırma paketleri kapsamında yeşil yatırımlara en fazla yer veren ülkeler olmuştur. Oransal olarak toplam canlandırıcı yatırım paketi içinde \% 78'lik payla yeşil yatırımlara en fazla yer veren ülke Güney Kore olmuştur. Güney Kore'yi \% $34^{\prime}$ lük payla Çin ve \% 18 payla Fransa takip etmektedir. Çin 218 milyar USD'lık yeşil yatırım bütçesi ile yatırım büyüklüğü alanında G20 ülkeleri arasında ilk sırada yer almaktadır (UNEP, 2009b: 2-3).

Iklim değişikliğiyle mücadele ve ekonomilerin karbondan arındırılması G7 zirvelerinin de odağındadır. 26-27 Mayıs 2016'da Japonya'da gerçekleştirilen G7 Zirvesi'nde kabul edilen Liderler Bildirisi'nin önsözünde G20'de olduğu gibi hem Sürdürülebilir Kalkınma İçin 2030 Gündemi'ne hem de Paris Anlaşması'na dikkat çekilmiştir. Bildiride küresel ekonominin karbonsuzlaştrıımasını sağlayacak bir enerji sistemine geçiş için çabaların hızlandırılacağı ve sera gazı emisyonlarını azaltan bir ekonomik büyüme için temiz enerji, enerji verimliliği gibi alanlara yatııımın artıılacağı taahhüt edilmektedir. Bildiride, Paris Anlaşması'nda yer alan, ISı artş̧ını 1.5 ila 2 derece arasında sınırlandırma amacının teyit edilmesi de önemli bir noktadır. İklim finansmanı ve bu alanda hükümetlerin, özel sektörün, yatırımcıların ve finans kurumlarının rolleri iklimle bağlantılı olarak bildiride yer verilen başlıca konulardır. Gelecek büyüme stratejisi ve eğilimleriyle iligili son derece önemli bir karar da, şüphesiz etkin olmayan fosil yakıt teşviklerinin 2025 yılına kadar kaldırılması kararıdır (G7 Ise-Shima Leaders' Declaration, 2016).

Yeşil ekonomiye geçiş konusunda kararlı adımlar atan Avrupa Birliği'nde ise ekonomik dönüşüm sürecine temel oluşturan bir doküman olarak "Avrupa 2020: Akıllı, Sürdürülebilir ve Kapsayıcı Büyüme için Avrupa Stratejisi" dikkate alınabilir (EC, 2010). ilgili belgede, krizden çıkmak ve krizi firsata çevirmek konularında, ekonominin daha yeşil hale getirilmesinin temel bir strateji olarak kabul edildiği görülmektedir. Belgenin önsözünde Avrupa için bir dönüm noktasına gelindiği ve işlerin alışılageldiği şekilde devam etmesinin artk mümkün olmadığına dikkat çekilmektedir. Belgede, değişimin yönü ve içeriğine ilişkin olarak büyümeyle ilgili birbirini tamamlayan üç temel öncellik ortaya konmaktadır. Bunlar; bilgi ve innovasyonu temel alan bir ekonomin geliştirilmesi (akıllı büyüme); kaynak etkin, daha yeşil ve rekabetçi bir ekonominin desteklenmesi (sürdürülebilir büyüme) ve sosyal ve bölgesel uyumu sağlayacak yüksek istihdamlı bir ekonominin teşvik edilmesidir (kapsayıcı büyüme).

Belgede sürdürülebilir büyüme önceliği ile ilgili olarak, sera gazı salınımlarının 1990 yılına kıyasla en az yüzde 20 ve gerekli şartlar ${ }^{9}$ sağlandığında \% 30 oranında azaltılması, yenilenebilir enerjinin toplam enerji tüketimindeki payının \% 20'ye yükseltilmesi ve enerji verimliliğinde \% 20 artış sağlanması hedeflerine yer verilmiştir. Strateji belgesinde ayrıca her bir öncelik alanıyla ilgili gelişme ve ilerlemeyi hızlandıracak yedi temel girişim alanı başlığı belirlenmiştir. Söz konusu girişim başlıklarından özellikle 'Kaynakları Daha Verimli Kullanan Avrupa' girişimi sürdürülebilir büyüme hedefiyle uyumlu olarak tasarlanmıştır. Belgede temiz enerji ve enerjinin verimli kullanılması hedeflerine ulaşıldığı takdirde bunun 2020 yılına kadar petrol ve doğal gaz ithalinde 60 milyar avro'luk bir tasarruf sağlayacağı öngörülmektedir. Bu tasarruf sadece finansal değil aynı zamanda enerji güvenliği açısından da büyük bir önem taşımaktadır. Ayrıca, enerjinin \% 20'sinin yenilenebilir 
kaynaklardan sağlanması amacının Avrupa Birliği'nde 600.000'den fazla yeni iş imkânı yaratma potansiyeline sahip olduğu, buna \% 20'lik enerji verimliliği hedefi eklendiğinde rakamın 1 milyonu aşacağı öngörülmektedir.

Avrupa için Yeşil Yatırım Planı'nda da dönüşümün kapsam ve kararılığına bağlı olarak kazanımların artacağına dikkat çekilmektedir. Örneğin yeşil enerji dönüşümünün fosil yakıt ithalini sonlandırarak AB'ye 350 milyar avro tasarruf sağlayacağı, yeşil ürün ve teknolojiler konsunda lider bir pozisyona sahip olmanın ihracat kapasitesini arttrarak yıllık 25 milyar avro ilave gelir artışı yaratacağı belirtilmektedir. Ayrıca planda yenilenebilir enerji, enerji verimliliği ve emisyon azaltımı alanında daha hırslı ve kararlı hedeflerin belirlenmesinin (sırasıyla \% 45, \% 40 ve \% 60) 2020 yılına kadar ilave 2 milyon ve 2030 yılına kadar da yine ilave 2 milyon iş imkanı yaratacağına dikkat çekilmektedir (Greens/EFA, 2014: 25).

Kişi başına yüksek emisyon oranları ve tüketim eğilimi dikkate alındığında henüz yolun başında olsa da Avrupa Birliği'nin yeşil ekonomiye geçiş konusunda önemli adımlar attğı, çevre ve ekonomi politikalarını bütünleştirme konusunda ilerleme kaydettiği söylenebilir. Avrupa Birliği'nde çevrenin bozulmasını azaltan ve doğal kaynakların devamlılığını sağlayan çevre sanayisi sektörü, 2000 ile 2011 yılları arasında \% 50'den fazla büyümüştür. Bu sektör, 2008 yılındaki ekonomik krizden bu yana gelir, ticaret ve istihdam bakımından gelişen az sayıdaki ekonomik sektörden biri olmuştur (AÇA, 2015: 9).

Başta gelişmiş ülkeler ve Çin, Hindistan, Güney Kore, Brezilya gibi hızla gelişmekte olan ülkeler olmak üzere tüm dünya ekonomilerini etkileyen dönüşüm süreci kaçınılmaz şekilde Türkiye'de de yansımasını bulmuştur. Türkiye'ye ilişkin sürdürülebilir kalkınma ve çevresel sürdürülebilirlik göstergeleri ekonominin yeniden yapılandırılması ve yeşil ekonomiye geçiş konusunda açık sinyaller vermektedir (Bkz. Aşıcı: 2015). Sera gazı emisyon envanteri sonuçlarına göre 2014 yılı toplam seragazı emisyonu 1990 yılına göre \%125 artış göstermiştir (TÜiK, 2016a). Türkiye'de sanayinin yoğun olduğu nehir havzalarında nehirlerin su kalitesi IV. Sınıftır (çok kirlenmiş su) (ÇŞB, 2014). Özellikle sanayi tesislerinden kaynaklanan attklar da çevre ve insan sağlığı açısından önemli bir risk oluşturmaktadır.

Bilim, Sanayi ve Teknoloji Bakanlığı Verimlilik Genel Müdürlüğü tarafindan 12 Şubat 2015 tarihinde yayınlanan İmalat Sanayi Sürdürülebilir Üretim Göstergeleri'ne göre 2008-2012 döneminde imalat sanayi genelinde oluşan toplam attk miktarı \%15 ve atk yoğunluğu (katma değer başına oluşan attk miktarı) \%7,2 oranında artmıştır. 2008-2012 döneminde imalat sanayinde ekonomik büyüme (GSYH) ve toplam attk miktarı arasındaki ilişki incelendiğinde ise attk miktarının GSYH'dan daha hızlı artthğı, dolayısıyla herhangi bir ayrışma olmadığı gözlemlenmiştir. 2008-2012 döneminde imalat sanayi genelinde su kaynaklarından çekilen su miktarı \%36, su yoğunluğu \%27 oranında artmış, su verimliliği ise \%21,3 azalmıştır. 2008-2012 döneminde imalat sanayinde ekonomik büyüme ve su kaynaklarından çekilen toplam su miktarı arasındaki ilişki incelendiğinde, çekilen su miktarının GSYH'dan daha hızı arttı̆ı, dolayısıyla ekonomik büyüme ve su kaynaklarından çekilen su miktarı arasında herhangi bir ayrışma olmadığı gözlemlenmiştir (BSTB, 2015a).

Kaynak verimliliğinin en önemli bileşenlerinden biri olan atkların geri kazanımı ve geri dönüşümü konsunda da Türkiye'nin ciddi sorunları olduğu görülmektedir. OECD verileri Türkiye'de üretilen belediye atıklarının \%99'unun depolama (düzenli depolama alanları ya da çöp döküm sahaları) yoluyla bertaraf edildiğini ortaya koymaktadır. Geri kazanım ve geri dönüşüm oranı ise sadece \%1'dir (OECD, 2015: 50). TÜiK 2014 Belediye Atık İstatistikleri de benzer bir sonuç ortaya koymaktadır. 2014 yılında atık toplama ve taşıma hizmeti verilen belediyelerde toplanan 28 milyon ton attğın $\% 63,5^{\prime} i$ düzenli depolama tesislerinde, $\% 35,5^{\prime} i$ belediye çöplüklerinde, \%0,5'i kompost tesislerinde, \%0,5'i ise diğer yöntemlerle (açıkta yakma, dereye ya da göle dökme, gömme) bertaraf edilmiştir (TÜiK, 2015). Bilindiği üzere Avrupa Birliği ülkelerinde atığın düzenli depolama sahalarına gönderilmesi bir son çare olarak düşünülmekte, yeni depolama sahalarının yapımı sınırlandırılmakta, geri kazanım, geri dönüşüm ve enerji elde etme amaçlı yakma yöntemleri ile depolama sahasına gönderilecek atık miktarı azaltılmaya çalışılmaktadır. Bu yöndeki çabalar neticesinde Avrupa Birliği27 genelinde 1995 ve 2014 yılları arasında depolama yöntemi ile bertaraf edilen atık mikatarı \% 54 azalırken geri dönüştürülen atık miktarı \% 166 artmıştır (Eurostat, 2016).

Sanayi tesislerinden kaynaklanan attkların bertarafinda da durum belediye atıklarından farklı değildir. İmalat sanayi atık istatistiklerine göre 2014 yılında imalat sanayinde üretilen toplam atık miktarı 16 milyon tondur. Bu atığın yaklaşık 1 milyon tonu tehlikeli atıktır. Üretilen tehlikeli atığın yaklaşık \% 60'ı satılmış ya da 
lisanslı atık bertaraf ve geri kazanım tesisine gönderilmiştir. Kalan \% $40^{\prime}$ 'ık kısım ise - oranlar için 'gizli veri' ifadesi kullanılmakla birlikte - çöplüğe atma, düzenli depolama, işyeri sahasında depolama yöntemleri ile bertaraf edilmiştir (TÜiK, 2016b).

Türkiye'nin enerji alanında dışa bağımlılığı da yeşil ekonomiye geçiş için daha kararlı adımlar atıması gerektiğini göstermektedir. Türkiye'de mevcut enerji talebinin yaklaşık \% $75^{\prime} \mathrm{i}$ ithal yolla karşılanmaktadır. Enerji tüketiminde fosil yakıtların payı yaklaşık \%90 ve yenilenebilir enerjinin payı ise \%10'dur (Acar vd., 2015: 2). Türkiye, son on yıllık dönemde OECD ülkeleri arasında enerji talebi en hızlı artı̧ gösteren ülkedir (DB, 2016). Diğer taraftan enerji yoğunluğu yüksek (birim enerji başına elde edilebilen GSMH) yani enerji verimliliği düşüktür. Enerji güvenliliğinin sağlanması, artan enerji ihtiyacının karşılanması ve karbon emisyonlarının azaltılması için yenilenebilir enerji kaynaklarına ve enerji verimliliğine yönelik yatırımların artıılması gerekmektedir. Türkiye'de ve Dünyada Enerji Verimliliği Raporu'nda enerji verimliliğinden sağlanacak en az \% 25 enerji tasarruf potansiyelinin olduğu belirtilmektedir. Bu alanda yapılacak çalışmaların ayrıca 40.000 yeni iş sağlayacağı, imalat sanayinde üretim maliyetleri içinde enerji maliyetlerinin payını \% 850 arasında düşüreceği öngörülmektedir (TMMOM-MMO, 2008: 59).

Dünya ekonomisinde yaşanan gelişmelerle birlikte Türkiye'de de ekonomiyi sürüdürülebilir bir temel üzerine inşa etmeyi amaçlayan plan, politika ve stratejilerin geliştirildiği görülmektedir. Türkiye'nin 2023 hedefleri doğrultusunda hazırlanan ve 2014-2018 dönemini kapsayan Onuncu Kalkınma Planı; yüksek, istikrarlı ve kapsayıcı ekonomik büyümenin yanı sıra hukukun üstünlüğü, bilgi toplumu, uluslararası rekabet gücü, insani gelişmişlik, çevrenin korunması ve kaynakların sürdürülebilir kullanımı gibi unsurları kapsayacak şekilde tasarlanmıştır. 2015-2018 dönemini kapsayan Türkiye Sanayi Stratejisi Belgesinde ise "Kaynakların etkin kullanıldığı, daha yeşil ve rekabetçi sanayi yapısına dönüşümün sağlanması" temel bir stratejik hedef olarak belirlenmiştir (BSTB, 2015b). Sanayide yeşil üretimin özendirilmesi staretjide yer alan başlıca politikalardan biridir.

Bunun yanı sıra başta Elektrik Piyasası Kanunu ve Yenilenebilir Enerji Kaynaklarının Elektrik Enerjisi Üretimi Amaçılı Kullanımına İlişkin Kanun olmak üzere, AB müktesebatına uyumu da gözeten çok sayıda yasal düzenleme ile geçiş sürecinin yasal çerçevevesi oluşturulmaya çalışılmaktadır. Ayrıca 20.02.2012 tarihli Resmi Gazete'de yayınlanan Enerji Verimliliği Strateji Belgesi 2012-2023 ile 2023 yılında Türkiye'nin GSYiH başına tüketilen enerji miktarının (enerji yoğunluğunun) 2011 yılı değerine göre en az \%20 azaltılması hedefi belirlenmiştir. İklim Değişikliği Ulusal Starejisi, İklim Değişikliği Eylem Planı, Geri Dönüşüm Strateji Belgesi, Akıllı Ulaşım Sistemleri Strateji Belgesi ve Eylem Planı da bu çerçevede değerlendirilecek başlıca dokümanlardır. Yeşil ekonomiye ilişkin koşul ve gerekliliklerin, hukuki ve siyasi düzenlemelere yansımaya başlamış olması kuşkusuz önemli bir gelişmedir. Ancak bu alanda yasal alt yapının güçlendirilmesi ve daha da önemlisi yeşil ekonomi politikalarının uygulanmasını sağlayacak bütüncül bir iradenin oluşması gerekmektedir. Bu noktada temel uygulayacı aktörler olarak özel sektör kuruluşlarının yeşil ekonomiye ilişkin algıları, böyle bir iradenin varlığının tespitinde önemli bir belirleyici hale gelmektedir. Bu çerçevede çalışmanın bundan sonraki kısmında özel sektör kuruluşlarının yeşil ekonomiye ilişkin algı ve tutumlarının belirlenmesine yönelik gerçekleştirilen araştırmanın sonuçları değerlendirilecektir.

\section{Araştırma Bulguları}

Firmaların yeşil ekonomiye ilişkin algı ve tutumlarını belirlemek üzere hazırlanan anket formu, Aralık 2015-Ocak 2016 tarihleri arasında ilgili firmalara elektronik posta yoluyla ulaştrılmıştır. ${ }^{10}$ Çalışmaya Bursa ilinde 8 ayrı OSB' de faaliyet gösteren 13 farklı sektörden 134 firma katılmıştır. ${ }^{11}$ Anket formunun ilk kısmında firmanın faaliyet gösterdiği OSB ve sektör, faaliyet süresi ve çalışan sayısı gibi tanımlayıcı sorulara yer verilmiştir. Anketin ikinci kısmı ise firmaların iklim değişikliği sorununa yaklaşımını belirlemeyi amaçlayan sorulardan oluşmaktadır. Sürdürülebilir gelecek başlığını taşıyan üçüncü kısımda ise firmaların çevresel meselelere ilişkin gelecek öngörülerini belirlemeyi hedefleyen sorular yer almaktadır. Anketin dördüncü kısmı, firmaların yeşil ekonomiye ilişkin tutumunu, tutumunu etkileyen faktörleri ve bu alanda karşılaştğ̆ı zorlukları/engelleri belirlemeye yönelik soruları içermektedir. Anketin son kısmı ise firmaların farkındalık düzeyini ölçmeyi amaçlayan sorulardan oluşmaktadır. 
Anket sonuçlarına ilişkin tanımlayıcı istatistikler aşağıdaki tabloda özetlenmiştir. Firmaların sektörlere göre dağılımı incelendiğinde \% 67 gibi büyük bir çoğunluğun Bursa sanayisinde ağırlıklı bir yere sahip olan tekstil ve otomotiv sektörlerinde faaliyet gösteren firmalar olduğu göze çarpmaktadır. Ankete katılan firmalar istihdam ettikleri kişi sayısına göre küçük, orta ve büyük ölçekli firmalar şeklinde gruplandırılmıştır. Buna göre ankete katılan firmaların \%26'sı küçük, \%28'i orta ve $\% 46$ 'sı da büyük ölçekli firmalardan oluşmaktadır. ${ }^{12}$ Firmaların sektördeki faaliyet sürelerine göre dağılımına bakıldığında ise \%45'inin bulundukları sektördeki faaliyet sürelerinin 25 yıldan fazla olduğu görülmektedir.

Tablo 1. Tanımlayıcı İstatistikler

\begin{tabular}{|l|l|l|l|l|l|}
\hline \multicolumn{2}{|c|}{ Sektör } & \multicolumn{2}{c|}{ Firma Büyüklüğü } & \multicolumn{2}{c|}{ Faaliyet Süresi } \\
\hline Tekstil & $\% 36$ & Küçük & $\% 26$ & $0-5$ Yıl & $\% 9$ \\
\hline Otomotiv & $\% 31$ & Orta & $\% 28$ & $5-15$ Yıl & $\% 22$ \\
\hline Diğer $^{13}$ & $\% 33$ & Büyük & $\% 46$ & $15-25$ Yıl & $\% 24$ \\
\hline & & & & 25 Yıl + & $\% 45$ \\
\hline
\end{tabular}

Anketin ikinci bölümünde firmalardan iklim değişikliği ile ilgili karşılaşabilecekleri riskleri ve iklim değişikliğinden sağlayabilecekleri firsatları düşük(1), orta(2) ve yüksek(3) şeklinde derecelendirmeleri istenmiştir. Bu derecelendirmelere ilişkin sonuçlar aşağıdaki grafikte yer almaktadır.

Grafik 1. İklim Değişikliğine Bağlı Fırsatlar ve Riskler

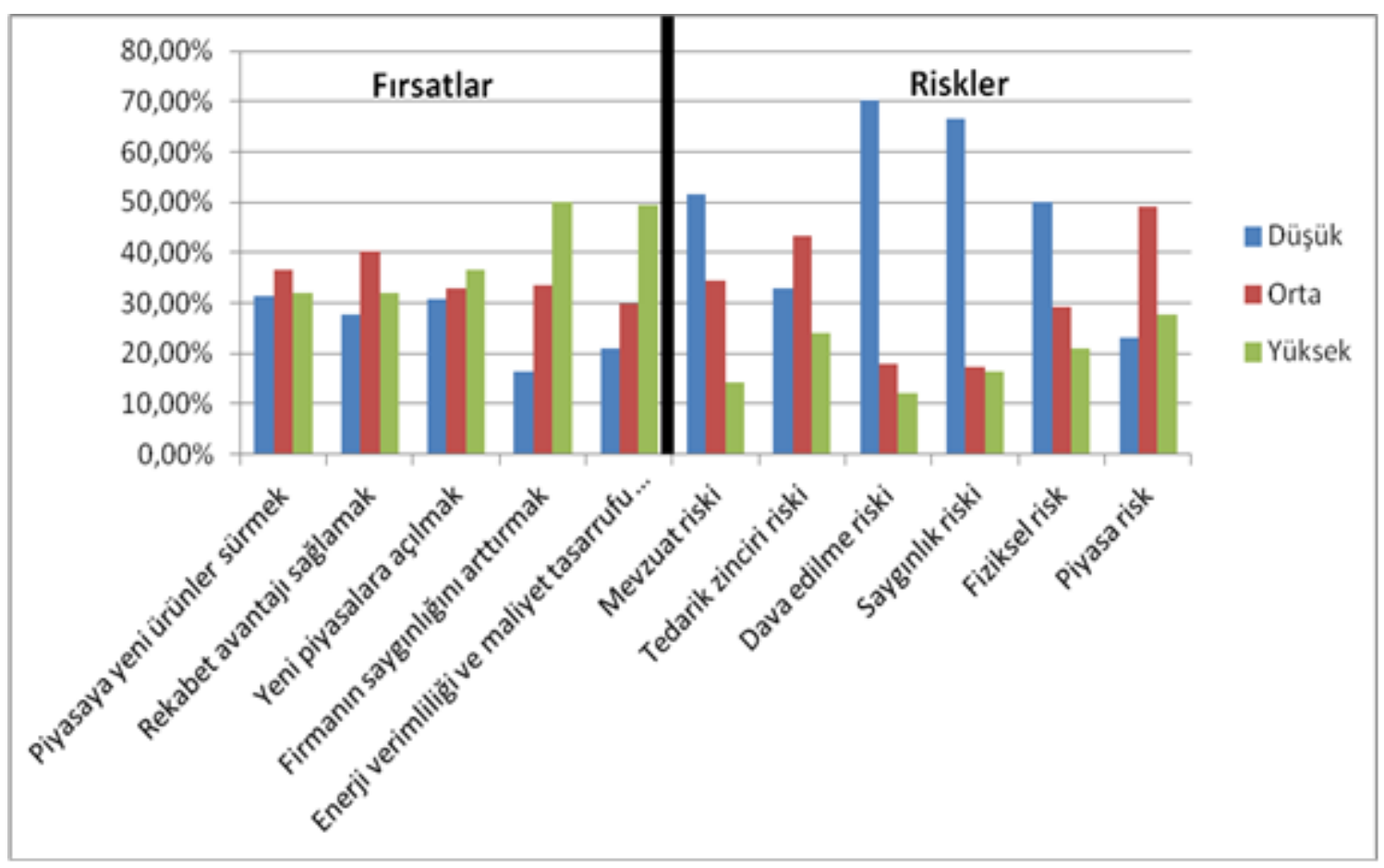

Fırsatlara ilişkin derecelendirmeye bakıldığında firmaların, 'firmanın saygınlığını arttırmak' ve 'enerji verimliliği ile maliyet tasarrufu sağlamak' seçeneklerini yüksek olarak değerlendirdikleri görülmektedir. 'Piyasaya yeni ürünler sürmek' ve 'yeni piyasalara açılmak' seçenekleri ise firsat anlamında düşük olarak derecelendirilmiştir. Risk derecelendirmelerinde ise 'piyasa riski (yüksek maliyetler nedeniyle rekabet gücü kaybı gibi)' en yüksek risk, 'dava edilme riski (kirletici emisyonlar için tüketicilerin açabileceği davalar)' en düşük risk olarak değerlendirilmiştir. Grafik genel olarak değerlendirildiğinde, firmaların iklim değişikliği sorununu riskten çok firsat olarak algıladıkları sonucuna varılabilir. Nitekim risk ve firsat derecelendirmelerine 
ilişkin hesaplanan genel ortalamaların risk için $1,70( \pm 0,50$ s.s), firsat için ise $2,13( \pm 0,64 \mathrm{~s} .5)$ olması bu çıkarımı desteklemektedir.

Firmaların iklim değişikliği sorusuna ilişkin risk ve firsat algısı, bu alandaki uluslararası araştırmaların sonuçlarıyla da uygunluk göstermektedir. Avusturalya'da 810 şirketin katkı sağladığı Çevresel Sürdürülebilirlik ve Endüstri araşatımasında, 'firma saygınlığını artırmak' ve 'maliyet ve enerji tasarrufu sağlamak' yüksek firsat sağlayacak alanlar olarak ön plana çıkarken, 'piyasa riski', risk derecelendirmesinde il sırada yer almaktadır (AIG, 2007: 19). UNEP, BMiDÇS ve Global Compact ortaklığıyla iş dünyasının iklim değişikliğiyle mücadeleye katkı sunmasını sağlamak amacıyla oluşturalan ve dünya genelinde 453 firmanın üye olduğu Caring for Climate girişiminin araştırma sonuçları ise araştırmaya katılan 72 şirketin \% 83'ünün iklim değişikliğinin ürün ve hizmetleri açısından bir risk oluşturduğunu; \% 86'sının ise iklim değişikliğiyle mücadeleye yönelik girişim ve yatırımların yeni firsatlar yaratacağını düşündüğünü göstermektedir (Karbassi vd., 2011: 6)

Firmaların iklim değişikliği ile ilgili risk ve firsatlara ilişkin olarak verdikleri yanıtlar ayrıca firma ölçekleri dikkate alınarak da değerlendirilmiştir. Bu değerlendirmede hem risk hem de firsatlar için sadece "yüksek" derecelendirmesi dikkate alınmıştır. Bu değerlendirme neticesinde ulaşılan sonuç; küçük ve orta ölçekli firmaların riskleri daha çok, büyük ölçekli firmaların ise firsatları daha çok yüksek olarak derecelendirdikleridir. Dikkat çekici bir sonuç da; küçük ölçekli firmaların enerji verimliliği ve maliyet tasarrufu sağlamayı buna karşın büyük ölçekli firmaların saygınlığı arttırmayı en yüksek avantaj sağlayacakları alan olarak değerlendirmeleridir.

Grafik 2. Firma Ölçeğine Göre İklim Değişikliğine Bağlı Riskler ve Fırsatlar

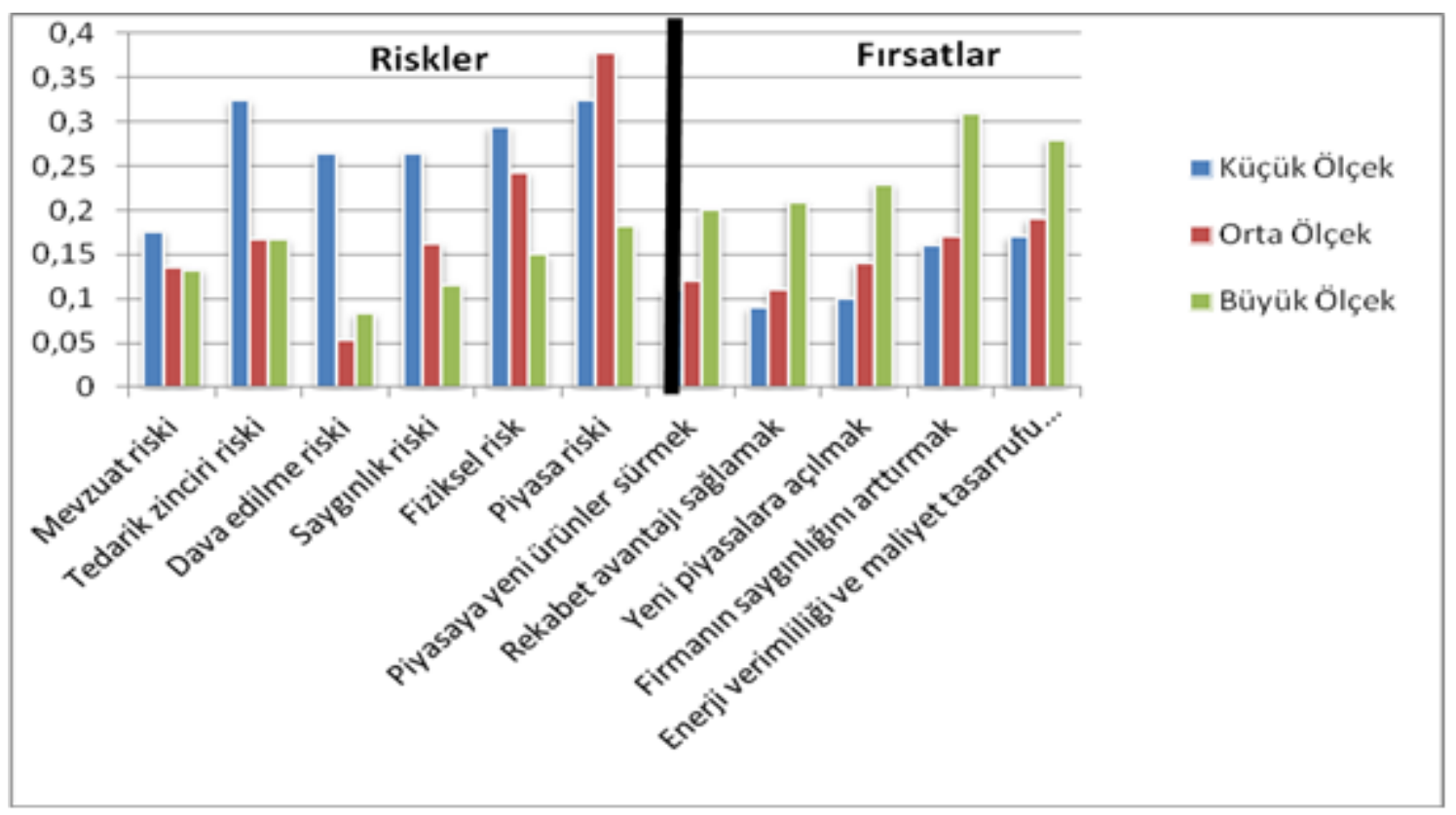

Ankette ayrıca firmalardan orta vadede iklim değişikliğinden sağlayabilecekleri firsatlar ile maliyetleri karşılaştırmaları istenmiştir. Buna göre firmaların \%34'ü maliyetlerin firsatları aşacağını, \%25'i firsatların maliyetleri aşacağını ve \%10'u da firsatların maliyetlere denk olacağını belirtmiştir. Firmaların \%31'i de bu konuda fikri olmadığını ifade etmiştir. Fırsatlar maliyetleri aşar cevabının firma büyüklüğüne göre dağılımı incelendiğinde bu cevabı veren firmaların çoğunluğunun yukarıdaki çıkarımla da tutarlı şekilde büyük ölçekli firmalar olduğu görülmektedir. Büyük ölçekli firmaların \%31'i, küçük ölçekli firmaların ise \%21'i firsatların maliyetleri aşacağını düşünmektedir. 
Grafik 3. İklim Değişikliğine Bağıı Fırsat ve Maliyetlerin Karşılaştırması

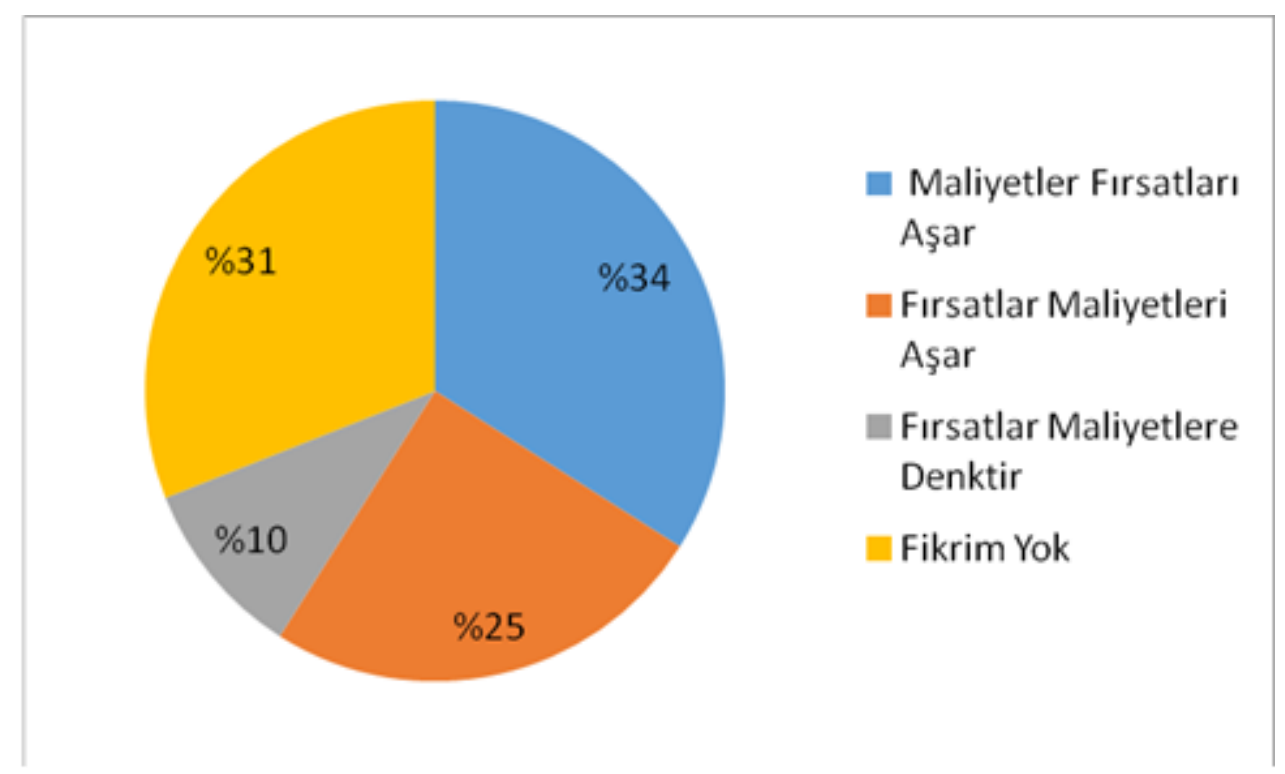

Grafik 4. iklim Değişikliğine Bağlı Fırsat ve Maliyetlerin Karşılaştrılması (Firma Ölçeğine Göre)

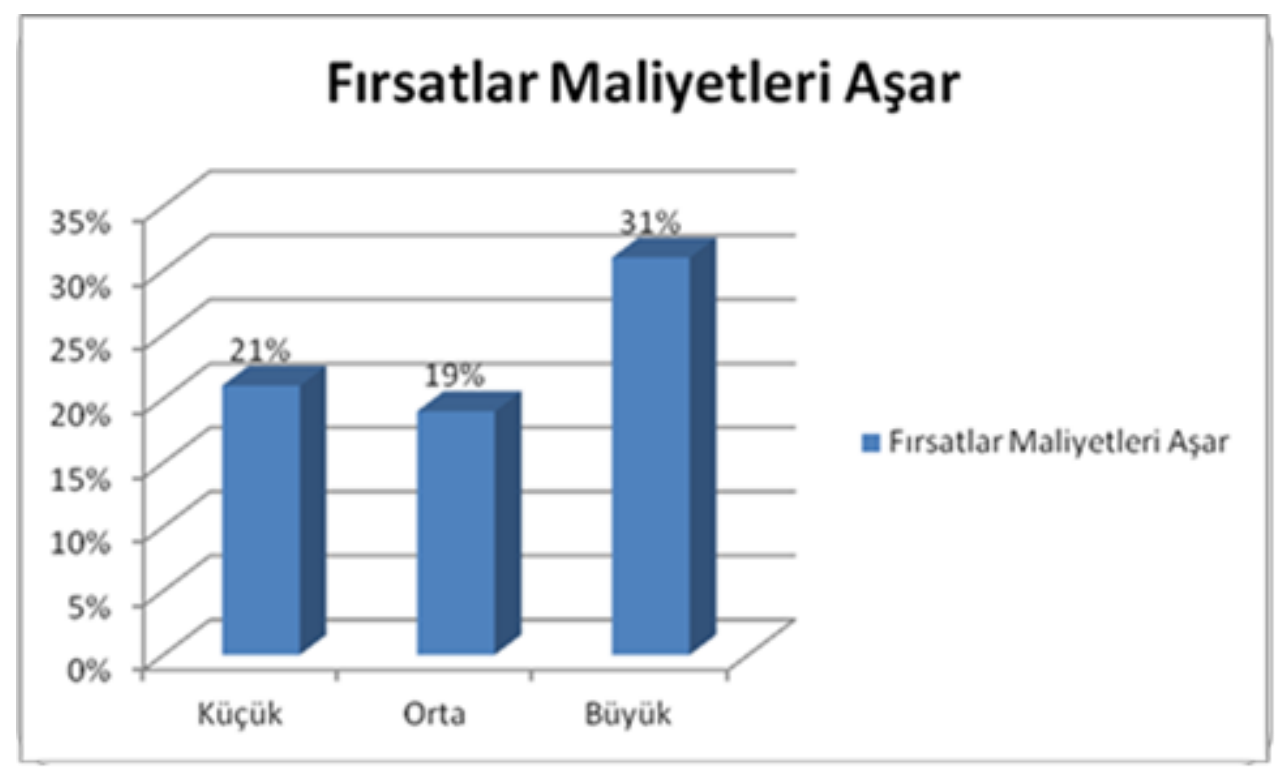

Bu soruya verilen yanıtlar, büyük ölçekli firmaların meseleye bakış açısını netleştirme açısından aydınlatıcı olsa da, konunun firmalar açısından ne denli karmaşık olduğunu da ortaya koymaktadır. Bu konuda fikri olmadığını belirten firmalar (\% 31) iklim değişikliğini firma için ne net kazanç, ne net kayıp ne de nötr bir durum olarak değerlendirmektedir. Firmalar her ne kadar iklim değişikliğini riskten ziyade bir firsat olarak görme eğiliminde olsalar da, firmaların sadece $\% 25^{\prime}$ i sağlayacakları firsatların iklim değişikliğiyle ilgili maliyetleri aşabileceğini düşünmektedir.

Ankette cevaplayıcılara, "firmaya ek maliyet getirecek olsa da, işletmenizin karbon emisyonlarının azaltıımasına katkı sağlama konusunda sorumluluğa sahip olduğunu düşünüyor musunuz?" sorusu sorulmuştur. Verilen yanıtlar, firmaların büyük oranda bu alandaki sorumluluklarını kabul ettiğini ortaya koymaktadır. Bu soruya hayır cevabını veren firmaların oranı sadece \% $5^{\prime}$ dir. Hayır cevabını veren firmaların

\%1'i küçük ölçekli, \%1'i orta ölçekli ve \%3'ü de büyük ölçekli firmalardır. Bu cevabın sektörlere göre dağılmına bakıldığında ise; tekstil \% 2,5 ; otomotiv $\% 1$; ağaç ve orman ürünleri $\% 0,7$ ve diğer $\% 0,8$ olduğu 
görülmektedir. Bu soruya verilen yanıtlar yukarıda belirtilen Çevresel Sürdürülebilirlik ve Endüstri (Avusturalya) araştırmasının sonuçlarıyla yüksek bir uyumluluk göstermektedir. Söz konusu araştırmada firmaların \% 78'i bu soruya evet, \% 16'sı fikrim yok ve \% 6'sı ise hayır cevabını vermiştir (AIG, 2007: 24).

Grafik 5. Emisyon Azaltımına Katkı Sağlama Sorumluluğu

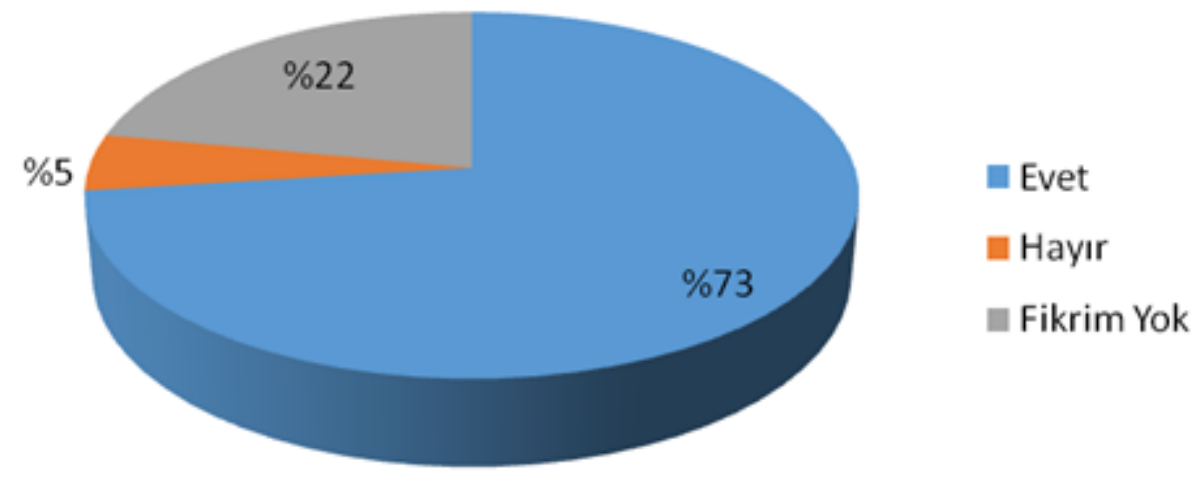

Ankette Sürdürülebilir Gelecek başlığı altında firmalara gelecek üç yılla ilgili olarak bazı çevresel konulardaki öngörüleri sorulmuştur. Bu sorulara verilen yanıtlar, aynı zamanda firmaların yeşil ekonomiye geçiş konusundaki algı ve tutumları hakkında da fikir vermektedir.

Grafik 6. Sürdürülebilir Gelecek

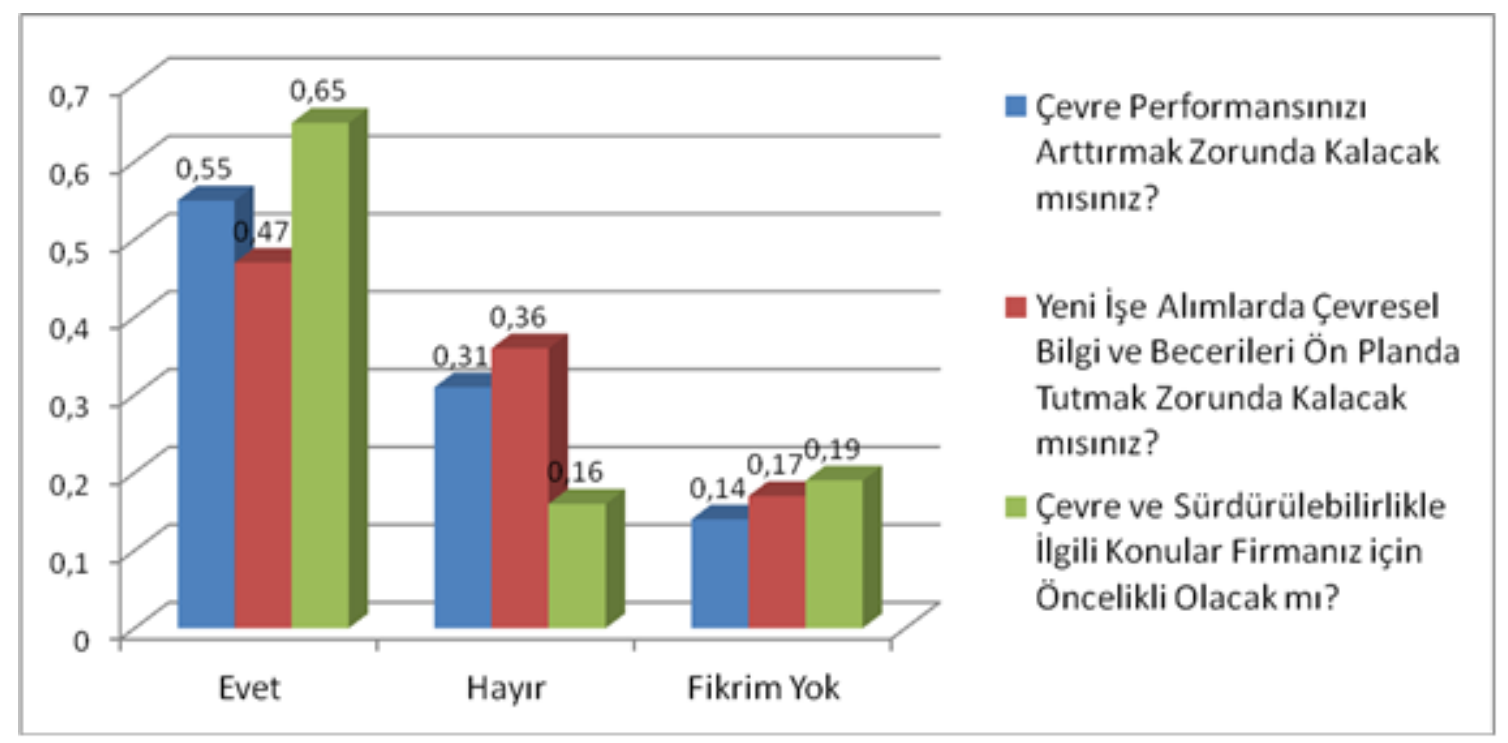

Grafikte de görüldüğü üzere firmaların \% 55’i gelecek üç yıl içinde çevre performansını artırmak zorunda kalacağını, \% 47'si yeni işe alımlarda çevresel bilgi ve becerileri ön planda tutmak zorunda kalacağını düşünmektedir. Firmaların \% 67 'si ise gelecek üç yıl içinde çevre ve sürdürülebilirlikle ilgili konuların firma için öncellikli hale geleceğini ifade etmektedir.

Anketin dördüncü kısmını oluşturan Tutum başlığı altında ilk olarak çevresel sürüdürülebilirlik ve yeşil ekonomiyle ilgili konularda firmaların tutumunu yansıtacak belirli ifadeler hazırlanmış ve firmalara bu ifadelere katılıp katımadıkları sorularak bir tutum ölçeği oluşturulmaya çalışılmıştır. Ifadelere verilen cevaplar Kesinlikle Katılmıyorum(1), Katılmıyorum (2), Karasızım (3), Katilıyorum (4) ve Kesinlikle Katlıyorum (5) şeklindedir. ${ }^{14}$ Cevaplar $5^{\prime}$ li likert ölçeğine uygun olarak hazırlanmış ancak yanıtlar değerlendirilirken katılma, katımama ve kararsızlık durumlarına göre gruplandırılarak ortalama değere ulaşılmıştır. Ölçek için 
hesaplanan Cronbach Alpha değeri 0,76 bulunmuştur. Bu da ölçeğin güvenilir olduğunu ortaya koymaktadır. Tutum ortalaması ise $2,56 \pm 0,36$ olarak hesaplanmıştır. Bu ortalama değer, firmaların çevresel sürdürülebilirlik ve yeşil ekonomiyle ilgili konularda olumlu yönde tutum sergilediklerine işaret etmektedir. Ifadelere verilen cevapların dağııımı aşağıdaki gibidir.

Tablo 2. Tutum Ölçeği

\begin{tabular}{|c|c|c|c|c|}
\hline & 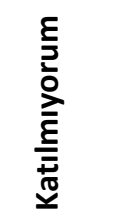 & 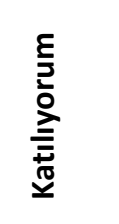 & 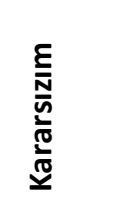 & 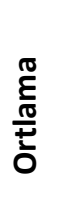 \\
\hline $\begin{array}{l}\text { 1-Firmamızın çevre performansının artması rekabet gücümüzü de } \\
\text { artıracaktır. }\end{array}$ & $\% 19,4$ & $\% 70,2$ & $\% 10,4$ & 2,50 \\
\hline $\begin{array}{l}\text { 2-Yeni piyasalar ve yeni iş alanlarına açılmada çevresel } \\
\text { sürdürülebilirlik önemli bir avantajdır. }\end{array}$ & $\% 15,7$ & $\% 75,3$ & $\% 9$ & 2,66 \\
\hline $\begin{array}{l}\text { 3-Gelecek yatırım kararlarımızı çevresel etkilerini de göz önünde } \\
\text { bulundurarak vereceğiz. }\end{array}$ & $\% 14,9$ & $\% 81,3$ & $\% 3,7$ & 2,77 \\
\hline $\begin{array}{l}\text { 4-Çevresel kriterlere/standartlara uyum sağlamak şirket saygınlı̆ıııın } \\
\text { önemli bir parçasıdır. }\end{array}$ & $\% 1,5$ & $\% 97$ & $\% 1,5$ & 2,95 \\
\hline $\begin{array}{l}\text { 5-Firmamızın çevre alanındaki faaliyetleri yasal zorunluluklarımızla } \\
\text { sınırıdır. }\end{array}$ & $\% 61,9$ & $\% 29,1$ & $\% 9$ & 1,67 \\
\hline $\begin{array}{l}\text { 6-Çevresel kriterlere uygun üretim yapmak ürün fiyatımızı } \\
\text { yükseltecektir. }\end{array}$ & $\% 53,7$ & $\% 23,9$ & $\% 22,4$ & 1,70 \\
\hline $\begin{array}{l}\text { 7-Çevresel kriterlere uygun üretim yapmak üretim maliyetlerimizi } \\
\text { yükseltecektir. }\end{array}$ & $\% 64,9$ & $\% 17,2$ & $\% 17,9$ & 1,52 \\
\hline $\begin{array}{l}\text { 8-Çevre ve sürdürülebilirlikle ilgili konuları işletme değerlerimizle } \\
\text { bütünleştirdik. }\end{array}$ & $\% 6,7$ & $\% 68,7$ & $\% 24,6$ & 2,61 \\
\hline $\begin{array}{l}\text { 9-Çevre ve sürdürülebilirlikle ilgili konuları tüm işletme } \\
\text { faaliyetlerimize entegre ettik. }\end{array}$ & $\% 9,7$ & $\% 61,9$ & $\% 28,4$ & 2,52 \\
\hline $\begin{array}{l}\text { 10-Çevre işletmenin tepe yönetiminin gündemindeki öncellikli } \\
\text { konulardan biridir. }\end{array}$ & $\% 15,7$ & $\% 63,4$ & $\% 20,9$ & 2,47 \\
\hline
\end{tabular}

Tutum ifadelerine verilen yanıtlar, sürdürülebilir gelecek sorularına verilen yanıtlarla da ilişkilendirilmeye çalışılmıştır. Tutum ve sürdürülebilir gelecek sorularına verilen yanıtlar arasında ilişki olup olmadığını istatistiksel açıdan değerlendirmek için Kruskal Wallis testi yapılmıştır. Test edilmek üzere ortaya konan hipotez şu şekildedir.

$\mathrm{H}_{\mathrm{A}}$ : Sürdürülebilir gelecek sorularına 'Evet' cevabını veren firmaların tutum ortalaması, 'Hayır' ve 'Fikrim Yok' cevabını verenlerden yüksektir.

Hipoteze göre gelecek öngörüleri, çevresel meseleleri daha fazla dikkate almak zorunda kalma yönünde olan firmalar (yani sorulara evet cevabını verenler) çevre ve sürdürülebilirlikle ilgili konularda olumlu bir tutum sergilemektedir.

Kruskal Wallis testinin sonuçlarına göre; tutum ortalaması sürdürülebilir gelecek sorularına verilen cevaplar açısından \%5 anlamlılık düzeyinde istatistiksel olarak anlamlı bir farklılık göstermektedir. Buna göre sürdürülebilir gelecek için olumlu yönde öngörüde bulunanların (yani evet diyenler) tutum ortalaması olumsuz öngörüde bulunanlardan (yani hayır cevabı) daha yüksektir. 
Tablo 3. Kruskal Wallis Testi Sonuçları

\begin{tabular}{llll}
\hline & Krsukal Wallis H & $\mathbf{p}$ & Ortalama Fark \\
\hline S.9 & 14,71 & 0,002 & 0,43 (Evet>Hayır) \\
$\mathbf{S . 1 0}$ & 29,49 & 0,000 & 0,57 (Evet>Hayır) \\
$\mathbf{S . 1 1}$ & 34,53 & 0,000 & 0,70 (Evet>Hayır) \\
\hline
\end{tabular}

Tutum başlığının ikinci bölümünde ise firmalara çevresel sürdürülebilirlik ve yeşil ekonomiyle ilgili konularda davranış ve tutumlarını etkileyen faktörlerin neler olduğu sorulmuştur. Bu soruya verilen yanıtlarda en yüksek yüzdeye sahip faktörlerin mecbur bırakılma ya da zorunda kalma ile ilişkili olduğu görülmektedir. 'Yasal düzenlemeler ve cezalar', 'tedarikçi firmaların ya da ticaret yapılan firmaların talepleri', 'tüketicilerin ya da STK'ların baskısı' işletmelerin çevresel tutumunu/davranışını etkileyen başlıca dışsal faktörler olarak ön plana çıkmaktadır. Bunun dışında 'şirket saygınlığı/imajı' da işletmenin çevre performansını etkileyen önemli bir faktördür. Ancak verilen yanıtlar doğrultusunda işletmelerin çevre performansını artırma ile kâr payını artırma, rekabet avantajı sağlama, pazar payını genişletme gibi klasik işletmecilik amaçları arasında doğrudan bir ilişki kurmadığı anlaşılmaktadır. Örneğin firmaların sadece yüzde 23'ü üretim maliyetlerini düşürmeyi, çevre performansını artırmayı tetikleyen bir faktör olarak görmektedir. Destekleyici bir veri olarak, tutuma ilişkin ifadeler dikkate alındığında (bkz. Tutum 7) firmaların \%65'inin 'çevresel kriterlere uygun üretim yapmak üretim maliyetlerimizi yükseltecektir' ifadesine katıldığı görülmektedir. İki cevabı bir arada düşündüğümüzde firmaların çevre performansını artırmayı, üretim maliyetlerinin düşürülmesiyle değil, aksine üretim maliyetlerinin yükselmesiyle ilişkilendirdikleri sonucuna ulaşılabilir.

Tutum ve davranışı etkileyen faktörler kapsamında 'yeni pazarlara açılma ve yeni iş firsatları yakalama' seçeneğini işaretleyenlerin oranı \%31'dir. Oysa tutum kısmında 'Yeni piyasalar ve yeni iş alanlarına açılmada çevresel sürdürülebilirlik önemli bir avantajdır' ifadesine katllanların oranı \% 75 'dir. Cevaplar arasındaki bu fark, belirli avantaj ya da firsatların varlığı kabul edilse bile, bu kabulün her zaman davranışsal değişime yol açmayacağını göstermektedir.

Grafik 7. Davranış ve Tututmu Etkileyen Faktörler

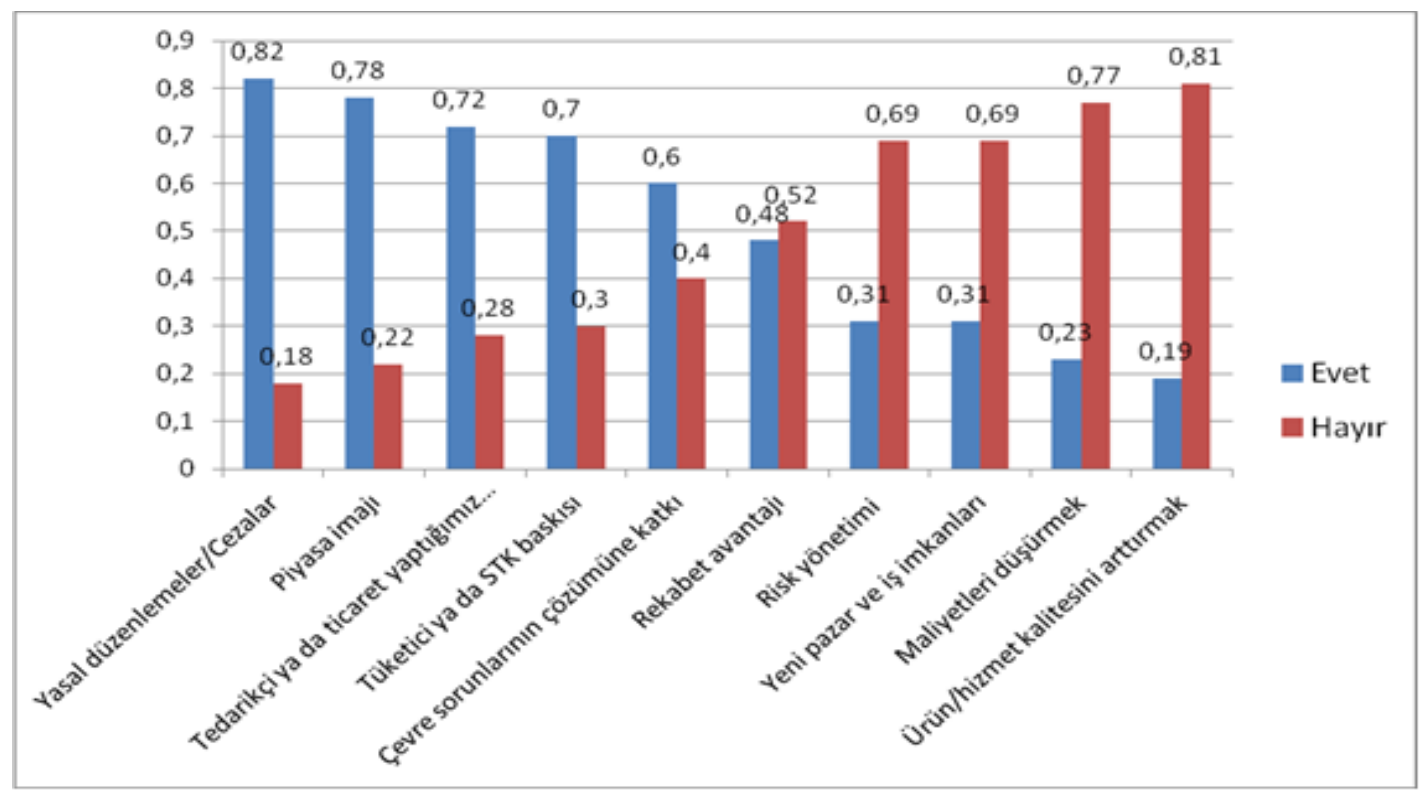


Tutum başlığı altnda son olarak firmalara çevresel sürdürülebilirliğin ve yeşil ekonominin gereklerini yerine getirme konusunda karşılaştkları engeller ve temel güçlükler sorulmuştur. Alınan cevapların dağılımı incelendiğinde en fazla yüzdeye sahip cevapların sırasıyla 'kamu desteğinin yetersiz olması', 'yüksek maliyet ve finansman güçlüğü', 'yapılan yatırımların uzun vadede geri dönüşüne karşılık kısa vadeli kazanç baskısı' olduğu görülmektedir. En düşük yüzdeye sahip cevaplar ise sırasıyla 'işletme birimlerinin uygulamada sürdürülebilirlik girişimleri ile bütünleşememesi', 'bu alanda uzman personelin bulunmaması' ve 'çevre ve sürdürülebilirlikle ilgili konuların firma için öncellik teşkil etmemesi'dir.

Grafik 8. Engeller/Güçlükler

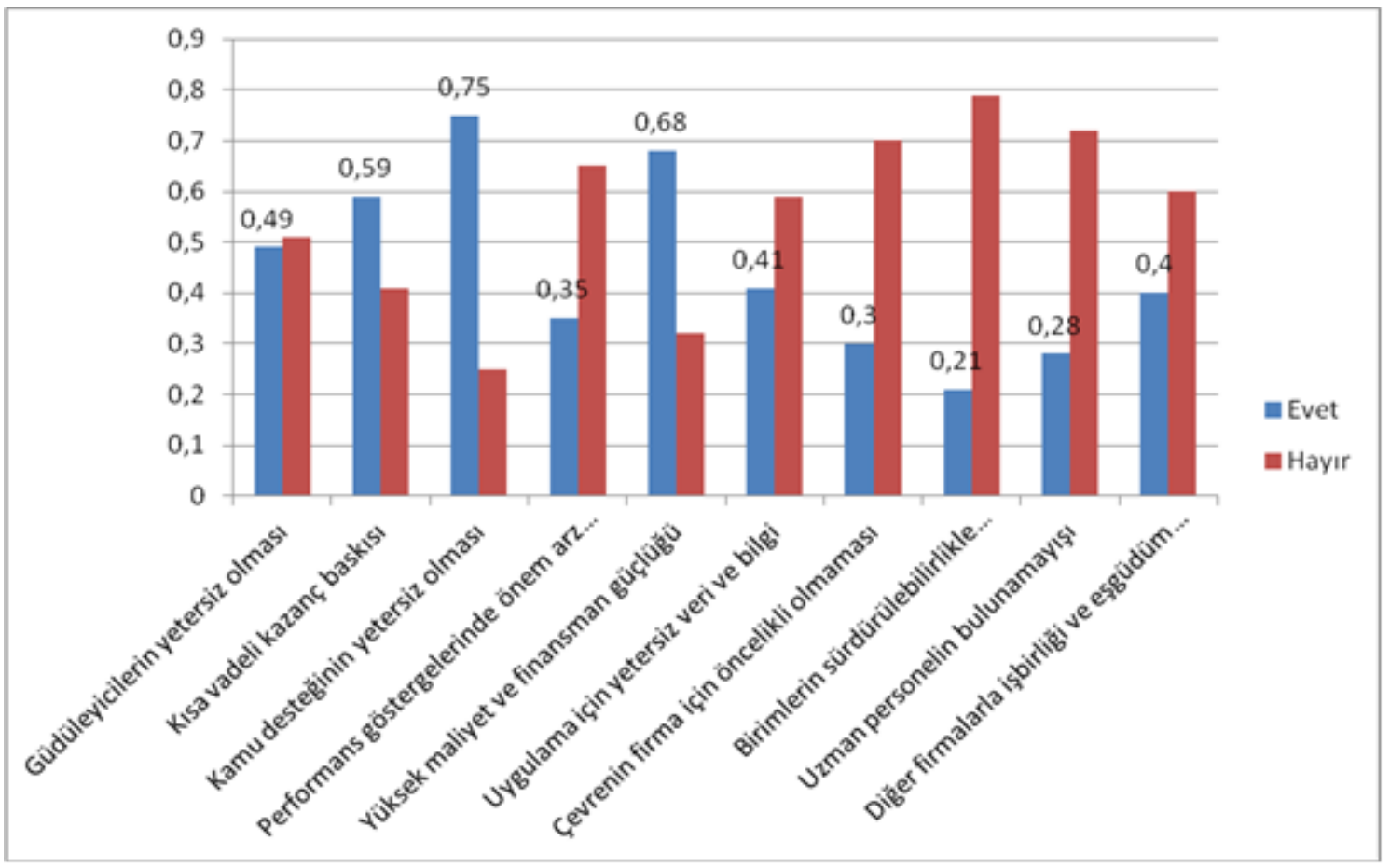

Anketin Farkındalık başlı̆̆ını taşıyan son kısmında ise firmalara farkındalık düzeylerini belirlemek amacıyla çevre ve sürdürülebilirlik ile ilgili bazı konularda bilgi düzeylerinin yeterli olup olmadığı sorulmuş ve bir farkındalık ölçeği elde edilmeye çalışılmıştır (Cronbach Alpha= 0,80). Farkındalık sorularına verilen cevapların ortalaması alınarak ortalama farkındalik ölçüsü (Ort=2,31 $\pm 0,49$ )hesaplanmıştır. Bu ortalama değer de firmaların çevresel konularla ilgili farkındalık düzeylerinin yeterliye yakın olduğu anlamına gelmektedir. Cevapların dağııımı aşă̆ıdaki gibidir.

Tablo 4. Farkındalık Düzeyi

\begin{tabular}{|c|c|c|c|c|}
\hline & 离 & $\begin{array}{l}\frac{N}{\omega} \\
\stackrel{ \pm}{ \pm} \\
\searrow\end{array}$ & 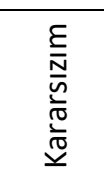 & $\begin{array}{l}\frac{\pi}{E} \\
\frac{\pi}{\pi} \\
\frac{\pi}{ \pm} \\
0\end{array}$ \\
\hline 1-Firmanın çevresel ayak izi & $\% 70,9$ & $\% 8,2$ & $\% 20,9$ & 2,50 \\
\hline $\begin{array}{l}\text { 2-Firmanın faaliyet gösterdiği sektöre ilişkin çevreyle ilgili yasal } \\
\text { düzenlemeler }\end{array}$ & $\% 88,1$ & $\% 8,2$ & $\% 3,7$ & 2,84 \\
\hline $\begin{array}{l}\text { 3-Firmanın çevre performansını artıracak kamunun sunduğu teşvik ve } \\
\text { imkânlar }\end{array}$ & $\% 38,1$ & $\% 32,1$ & $\% 29,8$ & 2,08 \\
\hline 4-Firmanın faaliyet gösterdiği sektördeki çevresel uygulamalar & $\% 67,9$ & $\% 13,4$ & $\% 18,7$ & 2,49 \\
\hline 5-Bu alanda faaliyet gösteren uluslararası kuruluşların çalışmaları & $\% 41$ & $\% 18$ & $\% 41$ & 2,00 \\
\hline $\begin{array}{l}\text { 6-Sektördeki diğer ulusal ve uluslararası firmaların yürüttüğü çevresel } \\
\text { uygulamalar }\end{array}$ & $\% 35,8$ & $\% 23,2$ & $\% 41$ & 1,94 \\
\hline
\end{tabular}


Farkındalık sorularına verilen cevapların ortalaması firmaların genel olarak konuyla ilgili yeterli bilgiye sahip olduğuna işaret etmektedir. Özellikle çevre üzerinde yaratılan baskı, yasal düzenlemeler ve sektördeki uygulamalar konusunda firmaların önemli bir bölümü yeterli bilgiye sahip olduğunu ifade etmiştir. Ancak çevre performasının artmasına katkı sağlayacak kamu tarafindan sunulan teşvik ve imkânlar ${ }^{15}$ konusunda yeterli bilgiye sahip olduğunu ifade eden firmaların oranı \%38'dir. Ayrıca yeşil ekonomi ve sürdürülebilirlik alanlarında faaliyet gösteren uluslararası kuruluşların çalışmaları ile sektördeki diğer ulusal ve uluslararası firmaların yürüttüğü çevresel uygulamalar konusunda kararsızlık seçeneği yüzdelerinin yüksek olması (\%41) bu alanda yeterli bilgiye sahip olmadıklarını düşündürmektedir. Söz konusu ifadeler firmaların bu alandaki ulusal ve uluslararası gelişmeleri takip edip etmedikleri ya da bu alandaki gelişmelerin farkında olup olmadıkları konusunda fikir vermeleri açııından önem arz etmektedir. Farkındalık soruları bağlamında ortaya çıkan sonuç, firmaların doğrudan kendileriyle ilgili olan alanlarda yeterli bilgiye sahip oldukları, ancak genel olarak yeşil ekonomi ve sürdürülebilirlik alanındaki gelişmeleri yeterli düzeyde takip etmedikleridir.

Tablo 5. Firma Ölçeğine Göre Farkındalık Değerlendirmesi

\begin{tabular}{lccccccccc}
\hline & \multicolumn{3}{c}{ Küçük Ölçek } & \multicolumn{3}{c}{ Orta Ölçek } & \multicolumn{3}{c}{ Büyük Ölçek } \\
\hline & Yeterli & Yetersiz & Kararsız & Yeterli & Yetersiz & Kararsız & Yeterli & Yetersiz & Kararsız \\
S-1 & $\% 68$ & $\% 6$ & $\% 26$ & $\% 67$ & $\% 14$ & $\% 19$ & $\% 75$ & $\% 5$ & $\% 20$ \\
S-2 & $\% 76$ & $\% 12$ & $\% 12$ & $\% 92$ & $\% 8$ & - & $\% 93$ & $\% 5$ & $\% 2$ \\
S-3 & $\% 38$ & $\% 32$ & $\% 30$ & $\% 35$ & $\% 43$ & $\% 22$ & $\% 40$ & $\% 25$ & $\% 35$ \\
S-4 & $\% 56$ & $\% 15$ & $\% 29$ & $\% 73$ & $\% 19$ & $\% 8$ & $\% 73$ & $\% 7$ & $\% 20$ \\
S-5 & $\% 35$ & $\% 24$ & $\% 41$ & $\% 46$ & $\% 19$ & $\% 35$ & $\% 42$ & $\% 13$ & $\% 45$ \\
S-6 & $\% 29$ & $\% 21$ & $\% 50$ & $\% 41$ & $\% 27$ & $\% 32$ & $\% 37$ & $\% 22$ & $\% 41$ \\
\hline
\end{tabular}

Farkındalık sorularına verilen cevaplar firma ölçeğine göre değerlendirildiğinde ise büyük ölçekli firmaların tüm sorularda daha yüksek oranda 'yeterli' cevabı verdiği görülmektedir. Bu da büyük ölçekli firmaların küçük ölçekli firmalara göre farkındalık düzeylerinin daha yüksek olduğunu göstermektedir.

\section{Sonuç ve Değerlendirme}

Türkiye ekonomik faaliyetlerin hacmindeki artş̧a bağlı olarak çevresel ayak izi giderek genişleyen bir ülkedir. Çevresel göstergelerin ortaya koyduğu kritik tablo ve çevresel bozulmanın ekonomik faaliyetlerle olan bağlantısı, Türkiye için yeşil ekonomiyi politik bir tercih değil, zorunluluk haline getirmektedir. Sürdürülemez nitelik taşıyan, fosil yakıtlara dayalı, kaynak ve kirletici yoğun bir endüstriyel yapı ile yola devam etmek artık mümkün olmadığı gibi rasyonel de değildir. Türkiye, özellikle enerji verimliği ve yenilenebilir enerji alanlarında ciddi bir potansiyele sahiptir. Yeşil ve düşük karbonlu bir ekonomi yönünde atllan adımlar, enerji ithalinden sağlanacak tasarrufa ek olarak, enerji arz güveliği açısından da büyük önem taşımaktadır. Ayrıca, kaynakların etkin kullanılması, yeni iş ve istihdam alanlarının oluşması ve küresel rekabet gücünün artması gibi önemli ekonomik firsatlar söz konusudur. Bu noktada geçiş sürecini geriden takip etmek Türkiye için kayıptan başka anlam taşımayacaktır.

Geçiş sürecinde, çevre üzerinde yaratılan baskıdaki paya bağlı olarak, özel sektör kuruluşlarına önemli sorumluluklar düşmektedir. Ancak özel sektör kuruluşları en nihayetinde kâr amacı güden örgütlerdir ve bu örgütlerin faaliyetlerinde üretim maliyeti önemli bir belirleyicidir. Çevre performansını artıracak uygulamalar ise genel olarak firmalar için önemli bir maliyet unsuru olarak görülmektedir. Bu nedenle işletmelerin çevre performansının artırılmasında, yeşil ekonomin gerekleri ile işletme çıkarlarını bütünleştirebilmek son derece önemlidir. Bu alanda yapılan pek çok araştırma çevre performansını artırmanın işletmeye önemli firsatlar sağlayacağını ortaya koymaktadır. Bu yönde algıya sahip olan firmalar, yeşil ekonomiyi bir rekabet stratejisi olarak benimsemektedir. Bu bağlamda yeşil ekonomiye geçişi sağlayacak ya da kolaylaştracak en önemli koşul, işletmelerin yeşil ekonomiye ilişkin farkındalıkları ve yeşil ekonominin gereklilikleri ile kendi öz çıkarlarını bütünleştirmeleridir.

Araştırma sonuçları ankete katılan firmaların, yeşil ve düşük karbonlu ekonomi konusunda genel olarak olumlu bir algı ve tutuma sahip olduğunu göstermektedir. Firmaların çoğu çevre performansını 
artırmanın işletmeye belirli alanlarda firsat sağlayacağı görüşünde hem fikirdir. Ayrıca işletmelerin önemli bir bölümü çevre ve sürdürülebilirlikle ilgili konularda sorumluluğa sahip olduğunu kabul etmektedir. Buna rağmen firmaların çevresel performansla işletme çıkarları arasında doğrudan bir bağlantı kurduğunu söylemek güçtür. Firmaların önemli bir bölümü çevre performansını artırmanın firma için bir maliyet unsuru olduğunu düşünmektedir. Bu durum firmaların sürece gönüllü ve proaktif bir biçimde katılımını engellemektedir. Nitekim araştırma sonuçları da firmaların çevre performansını belirleyen en önemli faktörün yasal zorunluluklar olduğunu göstermektedir. Ayrıca yine firmaların önemli bir bölümü çevresel uygulamalarının yasal düzenlemelerle sınırlı olduğunu belirtmiştir. Kısacası işletmeler, yeşil ekonomin sağlayacağı firsat ve avantajlar konusunda olumlu bir algıya sahip olsalar da bu durum davranışsal anlamla olumlu sonuçlar üretmeye yetmemektedir. Araştırma bulgularına dayanarak özel sektör kuruluşlarının geçiş sürecine ayak direyen, engelleyici yapılar olmadığı aksine bu süreci destekleme niyetinde oldukları söylenebilir. Destekleyici rollerini pekiştirme konusunda ise bu alanda karşılaştkkları engellerin giderilmesine odaklanılmalıdır. Kamu desteğinin yetersiz olması, yüksek maliyet ve finansman güçlüğü gibi sorunların aşılması, firmaların bu sürece daha aktif katılımını sağlayacaktır. Kamu sektörünün bu alandaki öncü ve yönlendirici rolünün güçlendirilmesi ve finansman güçlüğünü aşacak şekilde yeşil finansman araçlarının geliştirilmesi yönünde atlacak adımlar sürece önemli katkı sağlayacaktır. Diğer taraftan firmaların yeşil ekonomiye ilişkin uluslararası gelişmeleri ve uygulamaları takip etmesi de hem özel sektörün sürdürülebilirliğinin sağlanması hem de küresel rekabet gücünün geliştirilmesi açısından büyük önem taşımaktadır.

\section{Son Notlar}

1. Bu çalışma Uludağ Üniversitesi Bilimsel Araştırma Projeleri Komisyon Başkanlığı tarafindan desteklenen KUAP (i)2015/34 No'lu proje kapsamında hazırlanmıştır. Desteğinden dolayı Uludağ Üniversitesi Bilimsel Araştırma Projeleri Komisyon Başkanlığı'na teşekkür ederiz.

2. Ekolojik ayak izi, tüketilen doğal kaynakların yeniden üretimi ve tüketim neticesinde oluşan atkların emilimi için ne kadar kara ve su sahasına ihtiyaç duyulduğunu gösteren bir ölçüttür. Bu ölçüt doğal kaynakların tüketim hızılla dünyanın kendi kendini yenileme kapasitesini karşılaştırarak, var olan tüketimin sürdürülebilir olup olmadığını göstermektedir.

3. Gezegen eşikleri kavramı, 2009 yılında Stockholm Dirençlilik Merkezinde Johan Rockström öncülüğünde çalışmalarını yürüten bir grup Dünya Sistem Uzmanı tarafindan geliştirilmiştir. Belirlenen eşikler; iklim değişikliği, biyolojik çeşitlilik, azot ve fosfor, stratosferdeki ozon, okyanus asitlenmesi, küresel tatı su kullanımı, arazi kullanımındaki değişiklikler, atmosfere aerosol salınımı, kimyasal kirlilik ve birbirine bağı ş̧iklerdir.

4. Paris Analşaması, Madde 2. Anlaşma metni için bkz. http://unfccc.int/files/essential_background/convention/application/pdf/english_paris_agreement.pdf (Erişim Tarihi: 13.08.2016).

5. Yeşil ekonomiye ilişkin ulusal stratejiler konusunda ayrıntılı bilgi için bkz. Cameron Allen, A Guidebook to the Green Economy Issue 3: Exploring Green Economy Policies and International Experience With National Strategies, United Nations Division for Sustainable Development, UNDESA, 2012.

6. Ilgili yayınların kapsamlı bir dökümü için bkz. Cameron Allen ve Stuart Clouth, Guidebook to the Green Economy Issue 1: Green Economy, Green Growth, and Low-Carbon Development- history, definitions and a guide to recent publications, Division for Sustainable Development, UNDESA, 2012.; David Huberman, Green Economy Guidebook: A Guidebook for IUCN's Thematic Programme Area on Greening the World Economy (TPA 5), IUCN, Gland, Switzerland, 2010.

7. Ilgil rapora www.rec.org.tr adresinden ulaşılabilir. Sözkonsu araştırmanın ikincisine yönelik hazırlılar Ağustos 2016'da başlatılmış ve sonuçların Aralık 2016'da kamuoyu ile paylaşılacağı duyurulmuştur.

8. Roma Klubü'nün Büyüme Sınırları başlıkı Raporu (1972) ve E.F. Schumacher'in Küçük Güzeldir (1973) adlı eserleri bu bağlamda değerlendirilebilecek başlıca çalışmalardır.

9. Gerekli şartlardan kasıt, diğer gelişmiş ve gelişmekte olan ülkelerin de sera gazı emisyonlarını azaltma konusunda çaba göstermesidir. 
10. Anketlerin firma tüzel kişiliğini temsilen fimanın karar alama ve yönetim süreçlerinde görev alan yönetici, müdür, genel müdür vb. pozisyondaki kişiler tarafindan doldurulması talep edilmiştir. Mail yoluyla cevap alınmayan firmalardan ikinci aşamada randevu talep edilmiş ve anket elden ulaştırılmıştır.

11. Anketin uygulandığı tarih (Aralık 2015-Ocak 2016) itibarıyle Bursa ilinde 13 adet faal OSB bulunmaktadır. Bunlardan 5'i sadece belirli bir alana yoğunlaşan ihtisas OSB niteliğinde olduğu için araştırmanın kapsamı dışında bırakılmıştır. Anket uygulanan OSB'ler; Bursa OSB, Nilüfer OSB, Demirtaş OSB, Inegöl OSB, Kestel OSB, Gürsu (Uludağ) OSB, Hasanağa OSB, Mustafa Kemalpaşa OSB.

12. Çalışma'da Avrupa Komisyo'nun 2003 tarihli Tavsiye Kararında öngörülen, çalışan sayına göre Küçük ve Orta Büyüklükteki Işletme (KOBi) tanımı kullanılmıştır. Buna göre 50 kişiden az çalışana sahip işletmeler küçük ölçekli, 50 - 250 kişi arasında çalışana sahip işletmeler orta ölçekli ve 250'den fazla çalışana sahip işletmeler ise büyük ölçekli işletme olarak tanımlanmıştır.

13. Otomotiv ve Tekstil dışında kalan sektörlerin dağılımı şu şekildedir: Ağaç, Orman Ürünleri ve Mobilya \%5; Çimento, Toprak Ürünleri ve Madencilik \%2; Elektrik-Elektronik \%1; Enerji \%2; Plastik, Sünger ve Ambalaj \%2; Gıda, Tarım ve Hayvancılık \%4; Inşaat \%1; Makina ve Teçhizat Imalat \%8; Kimya \% 4 ve Diğer \% 4.

14. Ölçekte 5,6 ve 7 numaralı sorular ters çevrilerek kodlanmıştır.

15. Kamu tarafindan sunulan desteklere Kalkınma Bakanlığı, Kalkınma Ajansları tarafindan mali destek programları çerçevesinde sağlanan hibeler; TTGV tarafindan Ar-Ge ve teknolojik yenilik projelerine sağlanan kredi desteği ve danışmanlık hizmeti; Bilim, Teknoloji ve Sanayi Bakanlığı tarafindan sunulan Teknogirişim destekleri; KOSGEB Ar-Ge ve Inovasyon Programı ve Endüstriyel Uygulama Programı destekleri; TÜBiTAK TEYDEB bünyesinde yürütülen Ar-Ge ve Yenilik Destek Programları tarfindan sağlanan destekler örnek gösterilebilir. Ayrıca 5746 sayılı Araştırma ve Geliştirme Faaliyetlerinin Desteklenmesi Hakkında Kanun, 193 sayılı Gelir Vergisi Kanunu ve 5520 sayılı Kurumlar Vergisi Kanunları kapsamında Ar-Ge faaliyetlerine bazı indirim, istisna ve muafiyetler sağlanmaktadır. Ayrıca Yenilenebilir Enerji kaynaklarının Elektrik Enerjisi Üretimi Amaçlı Kullanımına Ilişkin Kanun (2005) kapsamında yenilenebilir enerji üreticilerine tarife garantisi sağlanmaktadır. Buna ek olarak yenilenebilir enerji yatırımları Genel Yatırım Teşvik Programı kapsamında sübvanse edilmektedir. Bu program, projelere KDV muafiyeti, gümrük vergisi muafiyeti ve yatırımın 6. Bölge'de yapılması şartıyla 10 yıllık gelir vergisi stopaj desteği sağlamaktadır.

\section{Kaynaklar}

Acar, S., Kitson, L., \& Bridle, R. (2015). Türkiye'de kömür ve yenilenebilir enerji teşvikleri. International Institute for Sustainable Development, https://www.iisd.org/gsi/sites/default/files/ffsandrens_turkey_coal_tk.pdf_(Erişim Tarihi, 11 Ekim 2016).

AÇA, 2015. Avrupa'da çevre: Durum ve genel görünüm 2015 - Sentez raporu. Avrupa Çevre Ajansı, Kopenhag.

AIG- The Australian Industry Group (2007). Environmental sustainability and industry road to a sustainable future. North Sydney, Australia.

Allen, C., \& Clouth, S., (2012). A Guidebook to the green economy issue 1: Green economy, green growth, and low-carbon development-history, definitions and a guide to recent publications. Division for Sustainable Development, UNDESA.

Allen, C. (2012a). A Guidebook to the green economy issue 2: Exploring green economy principles. United Nations Division for Sustainable Development, UNDESA.

Allen, C. (2012b). A Guidebook to the green economy issue 3: Exploring green economy policies and international experience with national strategies. United Nations Division for Sustainable Development, UNDESA.

Aşıcı, A., \& Şahin, Ü. (2012). Yeşil ekonomi. Ed. Yeni İnsan Yayınevi, İstanbul.

Aşıcı, A. A. (2015). On the sustainability of the economic growth path of Turkey: 1995-2009" Renewable and Sustainable Energy Reviews, 52, 1731-1741.

Bouzaher, A., Şahin, Ş., \& Yeldan, E. (2015). How to go green: A general equilibrium ınvestigation of environmental policies for sustained growth with an application to Turkey. Letters in Spatial and Resource Sciences, 8(1), 49-76.

BTSB (2015a). İmalat sanayi sürdürülebilir üretim göstergeleri, https://anahtar.sanayi.gov.tr/tr/news/imalat-sanayisurdurulebilir-uretim-gostergeleri-aciklandi/1991_(Erişim Tarihi, 08 Kasım 2016).

BTSB (2015b). Türkiye sanayi strateji belgesi 2015-2018, T.C. Bilim, Sanayi ve Teknoloji Bakanlığı. http://sanayipolitikalari.sanayi.gov.tr/Public/TurkiyeSanayiStratejisi (Erişim Tarihi: 2 Eylül 2016). 
Constantinos, C., Sørensen, S.Y., Larsen, P.B., \& Alexopoulou, S. (2010). SMEs and the environment in the European Union. PLANET SA and Danish Technological Institute, Published by European Commission, DG Enterprise and Industry.

ÇŞB (2014). Çevresel Göstergeler 2014. http://www.csb.gov.tr/gm/ced/ (Erişim Tarihi, 03 Şubat 2016).

DB (2016). Türkiye'nin enerji profili ve stratejisi. TC Dışişleri Bakanlığı. http://www.mfa.gov.tr/turkiye_nin-enerjistratejisi.tr.mfa (Erişim Tarihi, 07 Kasım 2016).

EC- European Commission (2010). Europe 2020 A strategy for smart, sustainable and inclusive growth, communication from the commission, $\quad \operatorname{COM}(2010) \quad 2020 \quad$ final. http://ec.europa.eu/eu2020/pdf/COMPLET\%20EN\%20BARROSO\%20\%20\%20007\%20\%20Europe\%202020\%20-\%20EN\%20version.pdf (Erişim Tarihi, 12 Eylül 2016).

EC (2013). SMEs, resource efficiency and green markets. Flash Eurobarometer 381.

EFFECT (2013). Low carbon economy policy and project review background paper I. Dialogue Platform on Energy and Resource Efficiency in the Baltic Sea Region. http://www.cbss.org/wpcontent/uploads/2015/06/EFFECT_Low_Carbon_Economy.-background-paper-1.pdf (Erişim Tarihi, 19 Ekim 2016).

Ehresman, G., \& Okereke, C. (2015). Environmental justice and conceptions of the green economy. Int Environ Agreements, Vol.15, 13-27.

Eurostat (2016). Municipal waste statistics. http://ec.europa.eu/eurostat/statisticsexplained/index.php/File:Municipal_waste_landfilled,_incinerated,_recy cled_and_composted_in_the_EU-27,_1995_to_2014_new.png (Erişim Tarihi, 04 Kasım 2016).

Folke, C. (2013). Gezegen eşiklerine saygı göstermek ve biyosferle yeniden bağlantıya geçmek. Dünyanın Durumu 2013, Worldwatch Enstitüsü, Çev. Cana Ulaş Ekiz-Çağrı Ekiz, İstanbul: İ̧̧ Bankası Kültür Yayınları.

Ford, L. (2011). Transnational actors in global environmental politics. G. Kütting. (Eds.). Global Environmental Politics: Concepts, Theories and Case Studies (pp. 27-41). Oxon: Routledge.

G20 Leaders' Communique Hangzhou Summit, 4-5 September 2016 http://www.g20.org/English/Documents/Current/201609/t20160906_3395.html (Erişim Tarihi, 22 Ekim 2016).

G20-GFSG (2016). G20 Green finance synthesis report. G20 Green Finance Study Group 15 July 2016.

http://www.g20chn.org/English/Documents/Current/201608/P020160815359441639994.pdf (Erişim Tarihi, 19 Ekim 2016).

G7 Ise-Shima Leaders' Declaration, G7 Ise-Shima Summit, 26-27 May 2016. http://www.mofa.go.jp/files/000160266.pdf (Erişim Tarihi, 20 Ekim 2016).

Greens/EFA (2014). A Green investment plan for Europe: A new path towards sustainable development, prosperity and quality jobs. https://www.greensefa.eu/fileadmin/dam/Documents/Policy_papers/Green_Investment_Plan_for_Europe_EN.pdf (Erişim Tarihi, 16 Ekim 2016).

Gregori, G.L., Cardinali, S., \& Palanga, P. (2014). How to create value for micro-businesses approaching the green economy. Greener Journal of Business and Management Studies, 4(1), 19-30.

Hahnel, R. (2014). Yeşil iktisat: Ekolojik krize karşı koymak. İstanbul: BGTS Yayınları.

Huberman, D. (2010). Green economy guidebook: A guidebook for IUCN's thematic programme area on greening the world economy (TPA 5). IUCN, Gland, Switzerland.

IPCC- Intergovernmental Panel on Climate Change (2015). Climate Change 2014: Synthesis Report, Geneva, Switzerland.

İklim Platformu (2010). 21. yy uygarlığını yakalamak düşük karbon ekonomisine geçişte teknoloji-finans-tedarik zinciri. Haz. Önder Algedik, Ed. Gülçin Özsoy. REC Türkiye ve TÜsiAD Ortak Yayını.

Karbassi, L., Park, J., Kasten, T., Munang, R., Coleman, H., Put del Pino, S., Metzger, E., \& Prowitt, S., (2011). Adapting for a green economy: Companies, communities and climate change a caring for climate report. UN Global Compact, UN Environment Programme, Oxfam and the World Resources Institute.

Kuszewski, J., \& Crowther, Y. (2012). Canada and the green economy. ACCA (the Association of Chartered Certified Accountants).

Kuşat, N. (2013). Yeşil sürdürülebilirlik için yeşil ekonomi: Avantaj ve dezavantajları - Türkiye incelemesi. Yaşar Üniversitesi Dergisi, 29(8), 4895-4916.

OECD (2015), Environment at a glance 2015: OECD indicators. OECD Publishing, Paris. 
Özçağ, M., \& Hotunluoğlu, H. (2015). Kalkınma anlayışında yeni bir boyut: Yeşil ekonomi. CBÜ Sosyal Bilimler Dergisi, $13(2), 303-324$.

Özsoy, C. (2011). Yeşil ekonominin dinamikleri: Yeşil işler ve beceriler. Finans Politik \& Ekonomik Yorumlar, 48(562), 1932.

Özsoy, C.E. (2015). Düşük karbon ekonomisi ve Türkiye'nin karbon ayak izi. Emek ve Toplum Hak-Iş̧ Uluslararası Emek ve Toplum Dergisi, 4(9), 198-215.

State of California (2010). California's green economy summary of survey results. State of California Employment Development Department Labor Market Information Division.

TMMOM-MMO (2008). Dünyada ve Türkiye'de enerji verimliliği. TMMOB Makina Mühendisleri Odası Oda Raporu. http://www.mmo.org.tr/resimler/dosya_ekler/a551829d50f1400_ek.pdf_(Erişim Tarihi, 07 Kasım 2016).

TÜík (2015). Belediye atık istatistikleri 2014, 28 Aralık 2015 Haber Bülteni, Sayı: 18777.

TÜiK (2016a). Sera gazı emisyon envanteri 2014, 18 Nisan 2016 Haber Bülteni, Sayı: 21582.

TÜiK (2016b). İmalat sanayi su, attksu ve atk istatistikleri 2014, 26 Ocak 2016 Haber Bülteni, Sayı: 21624.

TÜSIAD (2016). Ekonomi politikaları perspektifinden iklim değişikliğiyle mücadele. Proje Koordinatörü: Erinç Yeldan, Yayın No: TÜSIAD- T/2016 T/2016,12 - 583. http://tusiad.org/tr/yayinlar/raporlar/item/9388-ekonomipolitikalari-perspektifinden-iklim-degisikligi-ile-mucadele (Erişim Tarihi, 29.01.2017).

UNEP (2009a). Global Green New Deal: Prief. http://www.unep.org/pdf/A_Global_Green_New_Deal_Policy_Brief.pdf (Erişim Tarihi: 13 Nisan 2016).

UNEP (2009b). Global Green New Deal An Update for the G20 Pittsburgh Summit http://www.unep.org/pdf/G20_policy_brief_Final.pdf (Erişim Tarihi, 19 Ekim 2016).

UNEP (2011). Towards a Green Econom: Pathways to Sustainable Development and Poverty Eradication. http://web.unep.org/greeneconomy/resources/green-economy-report (Erişim Tarihi, 04 Mart 2015).

WB-World Bank (2012). Inclusive green growth the pathway to sustainable development. Washington DC

WWF-World Wildlife Fund (2014). Living planet report. http://assets.panda.org/downloads/wwf_lpr2014_low_res.pdf (Erişim Tarihi, 15 Ekim 2015).

Yalçın, A.Z. (2016). Sürdürülebilir kalkınma için yeşil ekonomi düşüncesi ve mali politikalar. Çankırı Karatekin Üniversitesi iiBF Dergisi, 6(1), 749-775.

Yeldan, E. vd. (2015). Türkiye Için düşük karbonlu kalkınma yolları ve öncelikleri. İstanbul Politikalar Merkezi ve WWF Türkiye.

http://awsassets.wwftr.panda.org/downloads/20151007_turkiye_icin_duuk_karbonlu_kalknma_yollar_ve_onc elikleri_rapor.pdf (Erişim Tarihi, 29.01.2017). 